\title{
Bush v. Gore through the Lens of Constitutional History
}

\section{Citation}

Michael J. Klarman, Bush v. Gore through the Lens of Constitutional History, 89 Calif. L. Rev. 1721 (2001).

\section{Published Version}

http://scholarship.law.berkeley.edu/californialawreview/vol89/iss6/2/

\section{Permanent link}

http://nrs.harvard.edu/urn-3:HUL.InstRepos:12933360

\section{Terms of Use}

This article was downloaded from Harvard University's DASH repository, and is made available under the terms and conditions applicable to Other Posted Material, as set forth at http:// nrs.harvard.edu/urn-3:HUL.InstRepos:dash.current.terms-of-use\#LAA

\section{Share Your Story}

The Harvard community has made this article openly available.

Please share how this access benefits you. Submit a story.

Accessibility 


\section{California Law Review}

Volume 89 | Issue 6

Article 2

December 2001

\section{Bush v. Gore through the Lens of Constitutional History}

Michael J. Klarman

Follow this and additional works at: http://scholarship.law.berkeley.edu/californialawreview

\section{Recommended Citation}

Michael J. Klarman, Bush v. Gore through the Lens of Constitutional History, 89 CAL. L. Rev. 1721 (2001).

Available at: http://scholarship.law.berkeley.edu/californialawreview/vol89/iss6/2

This Article is brought to you for free and open access by the California Law Review at Berkeley Law Scholarship Repository. It has been accepted for inclusion in California Law Review by an authorized administrator of Berkeley Law Scholarship Repository. For more information, please contact jcera@law.berkeley.edu. 


\title{
Bush v. Gore Through the Lens of Constitutional History
}

\author{
Michael J. Klarman $\dagger$
}

This Article considers the long-term implications of Bush v. Gore for the Court's institutional standing and legitimacy. First, the Article argues that if the Court's legitimacy turns on the legal soundness of its reasoning, the Court is in a lot of trouble, since few neutral and detached lawyers will be convinced that the result in Bush v. Gore was a product of anything but the conservative Justices' partisan preference for George W. Bush. Second, the Article considers the alternative premise that history's verdict on a Supreme Court ruling depends more on whether public opinion ultimately supports the outcome than on the quality of the legal reasoning or the craftsmanship of the Court's opinion. The Article canvasses some of the landmark decisions in American constitutional history-Dred Scott v. Sandford, Brown v. Board of Education, Furman v. Georgia, Roe v. Wade, and others-with the aim of deriving a list of factors that predict how particular rulings will affect the Court's reputation. Then, applying these factors, the Article predicts that the long-term consequences of Bush v. Gore for the Court's reputation are likely to be relatively minimal, mainly because half the country approves of the result and because the underlying issue will rapidly become obsolete.

On December 12, 2000, the United States Supreme Court, for the first time in its history, picked a president. ${ }^{1}$ By shutting down the statewide manual recount that had been ordered just days earlier by the Florida

Copyright (C) 2001 Califomia Law Review, Inc. Califomia Law Review, Inc. (CLR) is a Califomia nonprofit corporation. CLR and the authors are solely responsible for the content of their publications.

$\uparrow$ James Monroe Professor of Law, Albert C. Tate, Jr. Research Professor, and Professor of History, University of Virginia. I have henefited from the comments of Akhil Amar, Jack Balkin, Einer Elhauge, Barry Friedman, Howard Gillman, Hal Krent, Sandy Levinson, Michelle Morris, Richard Posner, Evan Schultz, and Mark Seidenfeld, and from numerous conversations with Mike Seidman. Special thanks to Daryl Levinson and Jim Ryan. I am also grateful to Barbie Selby, Kent Olson, and other reference librarians at the University of Virginia School of Law for helping to educate me about Florida election law during the election controversy and for research help with this Article. Peggy Cusack and Michelle Morris provided excellent research assistance.

1. See Bush v. Gore, 531 U.S. 98 (2000). 
Supreme Court, the High Court Justices ensured that George W. Bush would become the forty-third president of the United States. ${ }^{2}$

In this Article, I shall speculate on the long-term implications of this controversial ruling for the Court's institutional standing and legitimacy. My strategy will be to canvas some of the landmark decisions in American constitutional history-Dred Scott v. Sandford, Brown v. Board of Education, ${ }^{4}$ Furman v. Georgia ${ }^{5}$ Roe v. Wade, ${ }^{6}$ and others-with the aim of deriving a list of factors that predict how particular rulings will affect the Court's reputation. Then I shall consider how those variables apply to Bush v. Gore and predict that decision's long-term consequences.

The premise of this Article is that history's verdict on a Supreme Court ruling depends more on whether public opinion ultimately supports the outcome than on the quality of the legal reasoning or the craftsmanship of the Court's opinion. I do not intend to defend that premise here, other than to say that history's judgment on Brown v. Board of Education, the ultimate feather in the Court's constitutional cap, seems to confirm its plausibility. The legal reasoning in Brown was widely ridiculed at the time, both by White southerners distraught over the threat posed by the decision to their cherished "way of life" and by elite legal academics and judges deeply invested in the enterprise of "reasoned elaboration." 8 The Brown Court's dubious rendition of the original understanding of the Fourteenth Amendment, its willingness to overturn decades' worth of precedent sustaining the constitutionality of racial segregation, and its unprecedented invocation of sociological data in support of its legal conclusion rendered the decision susceptible to criticism, both from supporters and opponents of racial segregation. ${ }^{9}$ Yet, over the course of ensuing decades, Brown

2. The seemingly endless post-election newspaper recounts coming out of Florida only confirm that "the ultimate truth ... is probably beyond reach." David Corn, The Florida Fog, The NATION, Mar. 19, 2001, at 4. Whether Bush or Gore would have won the manual recount seems to depend on which counties were recounted, which standards were used for ascertaining voter intent, and whether overvotes were counted as well as undervotes. See, e.g., Martin Merzer, Review Shows Ballots Say Bush, Miami Herald, Apr. 4, 2001, at A1 (notwithstanding the headline, reporting that the wiuner of the presidential recount would have depended on how many counties were recounted and what standard was used, and noting the ironic result that Bush would have won on the lenient standard advocated by Gore and that Gore would have won on the stringent standard advocated by Bush).

3. 60 U.S. (19 How.) 393 (1857).

4. 347 U.S. 483 (1954).

5. 408 U.S. 238 (1972).

6. 410 U.S. 13 (1973).

7. See, e.g., Tom Brady, Black Monday (1955); James J. Kilpatrick, The Southern Case FOR SCHOOL SEGREGATION (1962).

8. See, e.g., Learned HaNd, The Bill of Rights 55 (1958) ("I have never been able to understand on what basis [Brown] does or can rest except as a coup de main."); Herbert Wechsler, Toward Neutral Principles of Constitutional Law, 73 HARv. L. REv. 1, 32-34 (1959) (criticizing the Court in Brown for its failure to justify its result on the basis of any "neutral principle").

9. See, e.g., sources cited supra notes 7-8; Edmond Cahn, Jurisprudence, 30 N.Y.U. L. Rev. 150 (1955); see also Michael J. Klarman, Brown, Originalism, and Constitutional Theory: A Response 
became a cultural icon, and the Court's vanguard role in the civil rights movement (at least relative to that of other governmental institutions) has enormously enhanced its prestige among the American people. ${ }^{10}$ This conversion of Brown from a target of vituperative legal and sociopolitical criticism into a cultural icon may suggest that the Court's long-term standing depends more on getting its decisions right, by which I mean ruling in a manner consonant with long-term public opinion, than on the quality of its legal reasoning.

Of course, this premise may be mistaken. The Justices themselves, for example, seem convinced of the opposite view: that the Court's legitimacy depends on its ability to convince observers that its rulings are based on sound legal primciple, rather than political calculation or personal preference. Thus, in reaffirming the vitality of the Court's landmark abortion rights decision, Roe v. Wade, the plurality opinion in Planned Parenthood v. Casey declared that "the underlying substance of [the Court's] legitimacy is of course the warrant for the Court's decisions in the Constitution and the lesser sources of legal principle on which the Court draws." justification would be no judicial act at all" and "[t]he Court must take care to speak and act in ways that allow people to accept its decisions on the terms the Court claims for them, as grounded truly in primciple, not as compromises with social and political pressures ...."12 Likewise, the plurality opinion in Bowers v. Hardwick observed that " $[t]$ he Court is most vulnerable and coines nearest to illegitimacy when it deals with judge-made constitutional law having little or no cognizable roots in the language or design of the Constitution."13

For the sake of the Court's legitimacy, one inust hope that the Justices are wrong about this, for it will be difficult to find neutral and detached lawyers who believe that Bush v. Gore was "grounded truly in principle" or "in the langnage or design of the Constitution," rather than in the conservative Justices' partisan preference for George W. Bush in the 2000 presidential election. ${ }^{14}$ In Part I of this Article, I shall try to demonstrate that the

to Professor McConnell, 81 VA. L. REv. 1881, 1931 (1995) (noting that in 1954 Brown "was not seen to be so obviously correct").

10. See, e.g., John C. Jefrries, JR., Justice Lewis F. Powell, JR. 330 (1994) (stating that Brown "is universally approved as both right and necessary[;] ... [m] ore powerful by far than any academic theory of constitutional interpretation is the legend of Brown"). For other similar statements, see the sources cited in Klarman, supra note 9, at 1928 n.125.

11. 505 U.S. 833, 865 (1992) (plurality opinion).

12. Id.

13. 478 U.S. 186, 194 (1986) (plurality opinion).

14. For some representative critiques of Bush, see Ronald Dworkin, A Badly Flawed Election, N.Y. REv. of Books, Jan. 11, 2001, at 53 (calling Bush "one of the least persuasive Suprente Court opinions that I have ever rcad"); Jeffrey Rosen, Disgrace, NEw REPUBL1c, Dec. 25, 2000, at 18 (noting that the Justices, "by not even bothering to cloak their willfulness in legal arguments intelligible to people of good faith who do not share their views, ... made it impossible for citizens of the United 
Bush result can be explained only in terms of the conservative majority's partisan political preferences. In Part II, I will consider the likely impact of this ruling on the Court's long-term institutional standing.

I

Bush v. Gore: LAW OR Politics?

Just one day after the Court rendered its decision in Bush v. Gore, Justice Clarence Thomas appealed to a group of high school students visiting the Court not to attribute the ruling to the Justices' partisan preferences: "I have yet to hear any discussion, in nine years, of partisan politics among members of the court."15 Chief Justice Rehnquist, asked by the press to comment on Thomas's remarks, agreed "absolutely" with his colleague's statement. ${ }^{16}$ It is an interesting question whether these two Justices genuinely believe their pretensions to nonpartisan decisionmaking. ${ }^{17}$ Court watchers, possibly less in need of self-delusion, are likely to regard such claims as preposterous.

As a preliminary matter, it is helpful to identify precisely what distinguishes Bush v. Gore from other cases of constitutional interpretation. Any serious student of constitutional law appreciates that political ideology necessarily influences constitutional interpretation. The text of the Constitution is so open-ended, and the debate over permissible sources of interpretation so inconclusive, that it is virtually impossible for a judge not to be influenced by political ideology when construing the Constitution. ${ }^{18}$ Thus, we should not be (and most of us are not) surprised when the Justices divide, along predictable political lines, when adjudicating the constitutionality of abortion restrictions, school prayer, gay rights, affirmative action, minority voting districts, and a wide variety of federalism issues, just

States to sustain any kind of faith in the rule of law ...."); Anthony Lewis, A Failure of Reason: The Supreme Court's Ruling Isn't Convincing, Prrtsburgh Post-Gazetre, Dec. 18, 2000, at Al3 (judging the decision "a dismal failure," judged by the standard of providing "reasoned arguments," and concluding that it "invites people to treat the court's aura of reason as an illusion"); Neal Katyal, Politics Over Principle, WASH. POST, Dec. 14, 2000, at A35 (calling the decision "lawless and unprecedented"); J. Dionne Jr., So Much for States' Rights, WASH. PoST, Dec. 14, 2000, at A35 (accusing the majority of "contort[ing] their own principles and creat[ing] new law"); Scott Turow, $A$ Brand New Game; No Turning Back from the Dart the Court Has Thrown, Wash. Post, Dec. 17, 2000, at B1 (quoting Terry Sandalow to the effect that the decision was "incomprehensible" and "an unmistakably partisan decision without any foundation in law").

15. Robert G. Kaiser, Opinion Is Sharply Divided on Ruling's Consequences, WASH. Post, Dec. 14,2000 , at A25.

16. Id.

17. See, e.g., Jack M. Balkin, Bush v. Gore and the Boundary Between Law and Politics, 110 YALE L.J. 1407, 1407 (2001) (wondering whether Justice Thomas "also told the students that he believed in Santa Claus, the Eastcr Bunny, and the Tooth Fairy").

18. See, e.g., Michael J. Klarman, Fidelity, Indeterminacy, and thc Problem of Constitutional Evil, 65 FordHAM L. Rev. 1740 (1997). 
to name some of the more prominent constitutional disputes adjudicated by the Rehnquist Court. ${ }^{19}$

Yet, Bush v. Gore is importantly different from these other constitutional cases. It is one thing to say that a judge's political ideology influences her constitutional interpretations. It is quite another to say that her partisan political preferences do. $^{20}$ The Bush outcome was not a product of the conservative Justices' political ideologies. As we shall see, these Justices' oft-professed commitment to federalism and to judicial restraint logically should have led them to the opposite result. Rather, the Bush outcome was a product of these Justices' partisan political preference for George W. Bush, which, for at least a couple of them, may have been enhanced by their desire to retire from the Court while a Republican President is in office to choose their replacements. ${ }^{21}$ Another way of stating the point is this: Had all the other facts in the Florida election imbroglio remained the same, but the situation of the two presidential candidates been reversed, does anyone seriously believe that the conservative Justices would have reached the same result? ${ }^{22}$ It is telling how even Republican cominentators defending Bush generally have refrained from arguing for this conclusion. ${ }^{23}$

19. See cases cited infra notes 242-243, 245-246.

20. See, e.g., Linda Greenhouse, Another Kind of Bitter Split, N.Y. Times, Dec. 15, 2000, reprinted in Bush v. Gore: The Court Cases and the Commentary 296, 299 (E.J. Dionne, Jr. \& William Kristol eds., 2001) [hereinafter BusH v. GoRE] (quoting law professor Suzanna Sherry making this same distinction between jurisprudential philosophy and partisan politics); Randall Kennedy, Contempt of Court, 12 AMER. Prospect 15, Jan. 2001, reprinted in BusH v. GoRE, supra, at 336-37 (urging the same distinction).

21. Evan Thomas \& Michael Isikoff, The Truth Behind the Pillars, NewsweEk, Dec. 25, 2000, at 46 (reporting Justice O'Connor's election eve remark that it was "terrible" that Al Gore had been projected to win Florida (and presumably the election) and her husband's explanation that this meant the couple's retirement from Washington, D.C., would have to wait another four years).

22. But see Richard H. Pildes, Democracy and Disorder, 68 U. CHI. L. REv. 695 (2001) (noting that the voting pattern of the Justices in Bush $v$. Gore closely mirrors that in several recent cases involving the constitutional law governing the political process, thus suggesting that simple partisan politics may not explain the Bush result). Republican defenders of Bush probably would respond that the liberal Justices likewise voted their partisan political preferences. Yet, it is not so clear that this is true. First, two of the Bush dissenters, Justices Souter and Stevens, were Republicans for most of their adult lives, and for all we know still consider themselves to be such. While both of these Justices do evince liberal voting pattems in constitutional cases, it seems unjustified to assume that either or both of them necessarily supported the Democratic presidential candidate in the 2000 election. Second, and more importantly, it is unfair to the four dissenters to assume that they would have voted the opposite way had the parties been reversed. The majority and dissenting opinions are similar in that cach set of Justices reached results that seem consistent with their partisan political preferences (on the dubious assumption, questioned above, that Souter and Stevens preferred Gore to Bush). The two sets of opinions are dissimilar, as I hope to show, in that the dissenters followed existing law, while the majority made up new (bad) law.

23. Conservative commentators defending the Court's ruling have tended to emphasize that the Court saved the country from a constitutional crisis, or that it was Gore who initially invited judicial resolution of the election controversy (and thus scarcely can be heard to complain when the Supreme Court provided that resolution), or that Democrats are hypocritical to complam of judicial activism, 
Thus, the result in Bush v. Gore depended on the order in which the parties' names appeared on the case caption. This is extraordinary. Every first-year law student is taught that a minimum requirement of the rule of law is that the outcome of cases ought not to vary simply as a result of reversing the parties to the litigation. It may simply be a failure of imagination, but I cannot think of another Supreme Court decision about which one can say with equal confidence that reversing the parties, and nothing else, would have changed the result.

If we broaden our perspective beyond constitutional litigation, however, an analogous instance does come to mind: the recent Clinton impeachment episode. Many observers plausibly concluded that the two parties' positions on the substantive standard for impeachment, as well as on related procedural issues, were entirely a product of their partisan commitments. That is, had it been a Republican president being impeached for identical behavior, the Democrats would have insisted on a lower threshold standard for impeachment, the necessity of the Senate pursuing an impeachment trial to its bitter end, and so forth.

While I think this is the right way to understand the Clinton impeachment, ${ }^{24}$ it still leaves one crucial distinction between that constitutional controversy and Bush v. Gore. The constitutional law of impeachment is highly indeterminate. The constitutional text is spare, the original intent evidence is conflicting and inconclusive, and precedents on impeachment are few and far between. ${ }^{25}$ Given this degree of constitutional indeterminacy, it was inevitable that partisan preferences would drive post hoc constitutional interpretations regarding Clinton's impeachment. Bush

which they invented. See, e.g., John Yoo, In Defense of the Court's Legitimacy, 68 U. CHI. L. REv. 775,789 (2001) (defending Bush on the ground that it brought "an end to the destructive partisan struggle ... that ... threatened to spiral out of control," rather than on the basis of the Court's legal reasoning); Paul A. Gigot, Liberals Discover the Tyranny of the Courts, WALL ST. J., Dec. 15, 2000, at Al6 (noting that "having turned the Supreme Court into a superlegislature, the left is now horrified to see what it's created" and defending the decision on the ground that "it saved the country another month of fighting before reaching the same result"); Charles Krauthammer, Defenders of the Law ...., WASH. Post, Dec. 15, 2000, at A41 (defending Bush on the ground that Democrats "tumed this into a lawyers' contest" and that the Court averted "a true constitutional crisis"); David G. Savage \& Henry Weinstein, 'Right to Vote' Led Justices to 5-4 Ruling, L.A. TIMES, Dec. 14, 2000, at Al (reporting the views of lawyer Carter Phillips, who defended the result but not the reasoning of Bush, and of law professor John Yoo, who agreed with the result but was "surprised" by the equal protection rationale subscribed to by the five conservative Justices); Fred Barbash, A Brand New Game, WASH. Post, Dec. 17,2000 , at B1 (conceding that the decision may have been "poorly reasoned" or attributable to "partisan motives," but denying that this makes it "illegitimate," and noting that Democrats frequently have embraced judicial activism). Few conservative commentators have undertaken the onerous burden of defending Bush on its merits. For a rare example of sueh a defense, see Michael W. McConnell, Two-and-a-Half Cheers for Bush v. Gore, 68 U. CHI. L. Rev. 657 (2001).

24. See Michael J. Klarman, Constitutional Fetishism and the Clinton Impeachment Debate, 85 VA. L. REv. 631, 654-55 (1999) (arguing that, in light of the "legal indeterminacy" surrounding impeachment, "it is natural and perhaps inevitable that the personal values of the interpreters will determine legal outcomes").

25. See id. at 631-50. 
v. Gore was importantly different because the constitutional law relevant to adjudicating that dispute was reasonably clear; the majority simply chose not to follow it. While the Clinton impeachment controversy illustrates partisan preferences dictating the resolution of constitutional indeterminacy, Bush v. Gore reveals partisan preferences trumping law.

This is a strong claim, though I believe it is one with which virtually all Democratic lawyers, and a fair number of Republican ones, will agree. A closer look at the reasoning of the majority and concurring opinions in Bush will determine whether this serious charge is a fair one.

The per curiam opinion, representing the views of the five conservative Justices, relies on two bases for its reversal of the Florida Supreme Court's decision ordering a statewide manual recount of presidential "undervotes," those ballots for which the voting machines could not ascertain the voter's intention, but a manual inspection inight. First, the majority rules that a manual recount of improperly-marked ballots, if conducted pursuant to standards no more precise than ascertaining the "intent of the voter," would violate the Equal Protection Clause of the Fourteenth Amendment. The principal objection, according to the majority, was the risk that identical ballots, from different counties or even from the same county, might be evaluated differently. ${ }^{26}$ Specifically, punch card ballots with partially detached chads or indented chads inight be counted by one counting team based on its interpretation of the "intent of the voter" standard, but not by another applying a disparate interpretation.

Second, the majority ruled that a remand to the Florida Supreme Court for an opportunity to devise more precise, uniforn standards to guide the manual recount, which inight alleviate any equal protection concerns, was impossible because of looining time constraints. Specifically, Bush v. Gore was handed down roughly two hours before midnight on December 12, the day on which resolution of the election contest had to be completed if Florida's slate of presidential electors was to enjoy the "safe harbor" from congressional challenge afforded by federal statute. Neither aspect of the majority opmion is persuasive.

The majority's equal protection rationale creates entirely new law. ${ }^{27}$ Never before had the Supreme Court (and perhaps not any other court either) intimated that application of a vague statutory standard like "intent of

26. Bush, 531 U.S. at 104-07. This is not the only equality concern the majority raises. The majority suggests that limiting a manual recount to undervotes (and excluding overvotes) and that using untrained personnel as vote counters also raised equal protection concerns. Id. at 107-10.

27. The plethora of states employing the "intent of the voter" standard in a wide variety of contexts, including manual recounts and the counting of write-in and absentee ballots, no doubt were surprised to leam that they have been acting unconstitutionally all along. For these state laws, see Bush, 531 U.S. at 124 n.2 (Stevens, J., dissenting). See also Brief of Respondent at 36, Bush v. Gore, 531 U.S. 98 (2000) (No. 00-949) (noting that before voting machines were invented, the "intent of the voter" standard was universally employed). 
the voter" in a manual recount violated the Equal Protection Clause because of the risk that identically marked ballots might be counted differently. ${ }^{28}$ Of course, to say that Bush $v$. Gore creates new equal protection law is not to say that it is wrong (except, of course, for Justice Scalia, who is on record as rejecting novel constitutional interpretations that forbid longstanding practices). ${ }^{29}$ The Supreme Court often is called upon to resolve novel constitutional controversies, and inevitably on such occasions it creates new law. The majority's equal protection rationale is objectionable not because it represents new law, but rather because it represents bad law-law that the conservative Justices almost certainly would have rejected in any other setting.

For starters, on the majority's own standard - that identically-marked ballots in different counties must be treated the same-the Florida presidential election plainly was unconstitutional, since identically-marked military absentee ballots were counted in some Republican-leaning counties, notwithstanding their failure to comply with state law, but were rejected in other counties. ${ }^{30}$ Moreover, if it violates the Equal Protection Clause to conduct a manual recount under a vague standard that might result in identical ballots being counted differently, then certainly it should be unconstitutional to use different ballot designs or different ballotreading technologies, if these yield substantially different likelihoods of a particular vote being counted. ${ }^{31}$ Studies have shown that undervotes were

28. See Brief of Respondent at $44-45$, Bush v. Gore (noting the prevalence of the "intent of the voter" standard and listing numerous judicial decisions applying it). It is worth pointing out that had the Florida Supreme Court prescribed a more specific formula for ascertaining the "intent of the voter," the conservative Justices probably would have ruled that the state court was changing state law and thus violating Article II. Bush, 531 U.S. at 105 (refusing to decide whether the state supreme court had authority under state statute to prescribe a more specific standard for manually counting votes); see also Gore v. Harris, 773 So. 2d 524, 526 (Fla. 2000) (per curiam) (noting that a more expansive definition "would have raised an issue as to whether this Court would be substantially rewriting the Code after the election"); Elizabeth Garrett, Institutional Lessons for the 2000 Presidential Election, 29 FLA. ST. U. L. REv. (forthcoming 2001) (manuscript at 14) (noting that the state supreme court "did not feel comfortable specifying substandards to discern voters' intent in a manual recount" because of the Article II concerns expressed by the Supreme Court in Bush I).

29. See, e.g., United States v. Virginia, 5 I8 U.S. 515, 568 (I996) (Scalia, J., dissenting); Rutan v. Republican Party of Illinois, 497 U.S. 62, 95 (1990) (Scalia, J., dissenting).

30. David Von Drehle et al., For Bush Camp, Some Momentum from a Memo, WAsH. Posr, Jan. 31,2001 , at AI.

31. See, e.g., Samuel Issacharoff, Political Judgments, 68 U. CHI. L. REv. 637, 650 (2001). Justice Souter, who disagreed with most aspects of the majority and concurring opinions, agreed that standardless manual recounts were "wholly arbitrary," and thus unconstitutional. Bush, 531 U.S. at 134 (Souter, J., dissenting). Unlike the majority, Souter did proffer an explanation for why standardless recounts were constitutionally distinguishable from the use of disparate voting mechanisms likely to yield different rates of nonvotes. Souter argued that local variety in the use of voting technology could be justified on the grounds of cost concerns, the desire for experimentation, and so forth. Standardless manual recounts, on the other hand, were simply arbitrary. While Souter purports to find the Florida manual recount unconstitutional on the basis of a minimum rationality standard, this is not the way that standard generally has been applied by the Court. See, e.g., Minnesota v. Clover Leaf Creamery Co., 449 U.S. 456, 466 (I981) (noting that the Equal Protection Clause requires only that a legislature 
five times more likely in Florida counties using punch-card ballots than in those using more modern, optical-scan ballots. ${ }^{32}$ Similarly, a potentially confusing "butterfly" ballot employed by Palm Beach County led to a much higher-than-normal rate of presidential overvotes, as did ballots im other counties that listed presidential candidates on two separate pages. ${ }^{33}$ Moreover, these county-to-county disparities in presidential undervotes and overvotes were correlated with race; heavily Black precincts across Florida were more likely to use antiquated voting equipment, which substantially increased the chances of ballots failing to register a vote in the presidential election. $^{34}$

One principal objective of the court-ordered manual recount in Florida was the amelioration of mequalities that resulted from the use of disparate voting technologies in different counties. ${ }^{35}$ Yet, the Bush majority does not

rationally could have concluded that a particular law serves a legitimate state purpose, not that it in fact does so); Williamson v. Lee Optical, 348 U.S. 483, 487-89 (1955) (noting that minimum rationality review is satisfied so long as the legislature reasonably might have concluded that a certain problem was worth addressing and that its chosen solution might be effective). Furthermore, it is not difficult to conjure possible explanations for a court (or legislature) declining to specify standards more specific than "the intent of the voter" to guide a manual recount. First, the same value in experimentation that Souter identifies with regard to voting machines seems to apply in the context of vote tabulation standards. The best way to decide upon the optimal standard might be for different counties to experiment with different standards and then compare notes. Second, "local variety" also might justify leaving it to county canvassing boards to use their discretion in defining more precise standards. It is easy to imagine the desirability of applying a different standard in evaluating ballot markings in precincts with lots of elderly voters, who might experience greater difficulty punching out chads. This sort of imagined justifieation is all that minimum rationality review generally requires. See, e.g., McGowan v. Maryland, 366 U.S. 420, 426 (1961) ("A statutory discrimination will not be set aside if any state of facts reasonably may be conceived to justify it."). Finally, the Florida court's refusal to prescribe a more specific standard is compellingly justified by its desire not to transgress on the state legislature's prerogatives with regard to the selection of presidential electors. For the state courts to prescribe a standard more specific than the legislature's "intent of the voter" would have invited Supreme Court reversal on Article II grounds. Under these circumstances, it was not "wholly arbitrary" for the Florida Supreme Court to refrain from prescribing more specific standards.

32. Ford Fessenden, Contesting the Vote: The Voting Machines, N.Y. Times, Dec. 1, 2000, at A29; see also Bush, 531 U.S. at 147 (Breyer, J., dissenting) (noting that voters in counties with different voting machines arrived at the polls "with an unequal chance that their votes will be counted"); id. at 126 n.4 (Stevens, J., dissenting) (noting that the percentage of "nonvotes," meaning undervotes and overvotes combined, in Florida counties using punch card ballots was $3.92 \%$, while the same rate in counties using optical scan technology was only $1.43 \%$ ).

33. See, e.g., Dan Keating, Democrats Had Most Voided Votes in Fla., Wash. Post, Jan. 27, 2001, at Al; Theodore M. Porter, It's Not in the Numbers, WASH. Post, Nov. 26, 2000, at B1; see also Jeffrey Rosen, Speed Kills Misjudge, New RepubLIc, Nov. 27, 2000, at 17 (noting that Bush's equal protection argument would render the butterfly ballot unconstitutional).

34. John Mintz, Florida Ballot Spoilage Likelier for Blacks, WASH. Post, Dec. 3, 2000, at AI; David Montgomery, Simmering Election Anger Incites Rights Leaders, WASH. Post, Jan. 5, 2001, at A10; see also Keating, supra note 33, at Al (noting that Republican-leaning counties were more likely to use modern vote-counting technology that reduced the likelihood of overvotes by alerting voters of the problem before they left the voting booth).

35. Bush, 531 U.S. at 147 (Breyer, J., dissenting); see also Rosen, supra note 33, at 17 ("By preventing states from correcting the counting errors that result from different voting technologies, the conservatives have precipitated a violation of equal treatment far larger than the one they claim to 
deign to explain why these other ostensible equal protection problems do not invalidate the entire Florida presidential election vote (or, for that matter, the entire nationwide presidential election, given that other states exhibit the same lack of uniformity in the way they conduct presidential elections) ${ }^{36}$ All the majority says with regard to these seemingly analogous equal protection difficulties is that its holding is limited to "the special instance of a statewide recount under the authority of a single state judicial officer," 37 and that "[t]he question before the Court is not whether local entities, in the exercise of their expertise, may develop different systems for implementing elections." 38 Why was that question not before the Court? Because, "[o]ur consideration is limited to the present circumstances, for the problem of equal protection in election processes generally presents many complexities." 39 So much for the requirement that courts engage in "reasoned elaboration." that invalidates the manner in which all states currently conduct elections can be a sensible one; the majority's rationale in Bush does just that.

The Court's equal protection rationale was so novel and far-fetched that Bush's lawyers came exceedingly close to not even bothering to raise ${ }^{\text {it. }}{ }^{41}$ When they did, moreover, it was treated very much as an afterthought, receiving less than two sentences of attention at the very end of a forty-five page brief in the Florida Supreme Court. ${ }^{42}$ I do not mean to suggest that a lawyer's failure to raise a particular legal argument, or her decision to invoke it almost as an afterthought, proves that the argument is a bad one. Lawyers, like everyone else, sometimes make mistakes and

avoid."); Akhil Reed Amar, Should We Trust Judges?, L.A. Times, Dec. 17, 2000, at M1 ("In fixating on the small glitches of the recount rather than on the large and systemic glitches of the machines, the justices turned a blind eye to the real inequality staring them in the faee ....").

36. See, e.g., Savage \& Weinstein, supra note 23, at A1 (quoting law professor David Cole to the effect that the majority's equal protection rationale means that "every state electoral system in the country is in violation," and reporting law professor Pamela Karlan making a similar point); Amar, supra note 35, at M1 (noting that throughout the country different counties used different ballots and different counting standards).

37. Bush, 531 U.S. at 109.

38. Id.

39. Id.

40. For the idea that courts are obliged to engage in "reasoned elaboration" and to invoke "neutral principles" to justify their decisions, see, for example, HenRY M. HART, JR. \& AlbERT M. Sacks, The Legal Process 164-70 (1958); Wechsler, supra note 8, at 11-12, 15-17.

41. James V. Grimaldi \& Roberto Suro, Risky Bush Legal Strategy Paid Off, WASH. Post, Dec. 17,2000 , at A32 (noting that the equal protection argument was "initially thought so weak" that Bush's lawyers thought it did not raise a substantial federal question); see also David Von Drehle, In Florida, Drawing the Battle Lines, WASH. Post, Jan. 29, 2001, at Al (noting serious divisions within the Bush camp and among Republican lawyers more generally as to whether the equal protection argument was even worth raising).

42. See Amended Brief for Appellees at 45, Gore v. Harris, 772 So. 2 d 1243 (Fla. 2000) (No. SC00-2431); see also Brief for Respondents at 35, Bush v. Gore (noting that petitioners raised their equal protection challenge to standardless recounts in just "one throwaway line" in the state supreme court). 
miscalculations. Still, there is a sense in which the ex ante calculation of lawyers as to what qualifies as a good legal argument is more revealing than the Court's post hoc determination. The Supreme Court enjoys such immense prestige that the conclusion by a majority of Justices that " $x$ " is a good legal argument almost conclusively proves it to be so..$^{43}$ Yet, unless we are to stipulate that the Court is not only "final" but also "infallible,"44 it must be that the Justices occasionally vindicate bad legal arguments. Because of this tendency of Supreme Court decisions retrospectively to validate the arguments upon which they are based, the ex ante judgments of lawyers-at least highly proficient ones, possessed of adequate incentives to raise all credible arguments-may be more reliable mdicia of what counted as a good legal argument at a particular point in time than are the Court's post hoc determinations. In this same sense, the nearly-universal conclusion of legal academics and political pundits, before the Supreme Court granted review on the second go-round in Bush, that no serious federal question existed indicates how farfetched the ultimately victorious equal protection argument was. ${ }^{45}$ Given the skepticism that these same conservative Justices elsewhere have evinced toward equal protection challenges to state political processes ${ }^{46}$ their willingness to intervene in Bush would not have been easy to predict.

43. See, e.g., Balkin, supra note 17, at 1444 (arguing that if "a handful of Supreme Court Justices thought that these arguments are not only plausible but convincing," they cannot be completely "off the wall"); Michael Perry, The Authority of Text, Tradition, and Reason: A Theory of Constitutional "Interpretation," 58 S. CAL. L. REV. 551, 566 (1985) ("[Just] about any choice a majority of the Supreme Court is likely to make would probably fall within [the] boundary [set by] accepted canons of judicial behavior, even in conjunction with the constitutional text.").

44. See Brown v. Allen, 344 U.S. 443, 540 (1953) (Jackson, J., concurring).

45. See, e.g., William Kristol \& Jeffrey Ball, Against Judicial Supremacy, WKLY. STANDARD, Dec. 4, 2000, at 10 (noting that "[i]t would ... be a mistake ... for Bush to put too much hope in the federal courts" because "[m]ost GOP-appointed judges will vote as federalists, for the right of states to prevail on election law," and thus will reject the equal protection argument); Charles Lane, Bush 's Appeal to High Court Raises Issue of Fairness, WASH. Post, Nov. 23, 2000, at A29 ("Even Republican lawyers who sympathize with Bush's case express doubt about the Bush campaign's... [equal protection] claim."); Editorial, The Election Road Narrows, N.Y. Times, Dec. 5, 2000, at A28 (noting, after the initial Supreme Court remand, that once the Florida Supreme Court revised its ruling to address the Court's Article II concem, "there is unlikely to be any federal issue that would warrant further review by the United States Supreme Court'); Charles Lane, Territory Is Uncharted for Court Action, Wash. Post, Nov. 10, 2000, at Al (describing the various state law disputes generated by the election and then noting that "[f]ederal law generally leaves the administration of elections for federal office up to the states, so the matter is likely to be settled in Florida's courts, with no ultimate appeal to the U.S. Supreme Court"); see also Scott Turow, No Turning Back From the Dart the Court Has Thrown, WASH. POST, Dec. 17, 2000, at B1 (noting that constitutional scholars "of all stripes" had predicted that the Supreme Court would not get involved in the case).

46. See, e.g., Davis v. Bandemer, 478 U.S. 109, I43, 145, 158, 161 (1986) (O'Connor, J., with Burger, C.J., and Rehnquist, J., dissenting) (warning against "the federal judiciary" becoming involved in "the most heated partisan issues," denying that the Equal Protection Clause provides "judicially manageable standards" for adjudieating political gerrymandering claims, and denying that "mainstream political parties" require federal judicial protection). 
Even after the majority identified an equal protection problem with the "standardless" recount, however, the ordinary remedy would have been to remand the case to the Florida Supreme Court, to afford it an opportunity to cure the problem. Instead, the per curiam opmion concluded that such a remedy would be pointless, since the December 12 "deadline" for resolving Florida's election contest was immediately at hand. ${ }^{47}$ The Court manufactured this deadline out of thin air. The federal statute identifying December 12 as a relevant date in the presidential election process plainly is a "safe harbor" provision, to be utilized or ignored by the states at their discretion; it operates as an instruction to Congress, when counting the states' electoral votes, not as a command to the states, to be enforced by the federal courts. ${ }^{48}$ Nothing in federal law requires that a state's presidential electors be appointed until the date set for the electors to meet and cast their votes, which was December 18, on the 2000 election calendar. The majority opinion does not dispute this point. Rather, it reads the Florida Supreme Court decision under review as declaring the state legislature's intention to take advantage of this federal safe harbor provision. Thus, to remand Bush to the state court would have been pointless, according to the majority, since under the Florida Supreme Court's own interpretation of state law any nianual recount had to be conipleted by the December 12 deadline. $^{49}$

One can only marvel at the disingenuousness of this conclusion. First, there is enormous irony in the Bush majority's eagerness to defer entirely to the Florida court's supposed conclusion regarding the significance of the December 12 safe harbor deadline under state election law. Three members of that majority could identify no other aspect of the state court's interpretation of state election law that warranted similar deference. The majority's posture on this issue is especially remarkable given the concurring Justices' statement that, in light of Article II concerns, "the text of the election law itself, and not just its interpretation by the courts of the States, takes on independent significance." 50 The text of Florida election law does not say a word about the federal safe harbor provision.

Second, to the extent that the Florida Supreme Court did emphasize in its opinion the significance of the December 12 deadline, ${ }^{51}$ it plainly was responding to the Supreme Court's earlier intervention in Bush v. Palm Beach County Canvassing Board, ${ }^{52}$ which essentially had coerced the

47. Bush, 531 U.S. at 110-11.

48. See id. at 124 (Stevens, J., dissenting); id. at 130 (Souter, J., dissenting).

49. Id. at 110. The concurring opinion makes this same point, emphasizing the "wish" of the state legislature to take advantage of the federal safe harbor provision, a wish that appeared nowhere in the statute, but only in the state supreme court opinion. Id. at 120-22 (Rehnquist, C.J., concurring).

50. Id. at 113 (Rehnquist, C.J., concurring).

51. Gore v. Harris, 772 So. 2d 1243, 1248 (Fla. 2000).

52. 531 U.S. $70(2000)$. 
Florida court, upon threat of reversal, to acknowledge the importance of the safe harbor provision. ${ }^{53}$ Thus, the Supreme Court first forced the Florida jurists to acknowledge the significance of the December 12 deadline, and then insisted that its own hands were tied with regard to permitting the manual recount to continue, given the Florida court's interpretation of the significance of the December 12 deadline. This is a nifty trick.

Third and most importantly, nothing in the Florida Suprenie Court opinion, and no sensible reading of state law, treated the December 12 safe harbor deadline as dispositive, regardless of any competing considerations. ${ }^{54}$ It is one thing to say that the Florida legislature would have wished, all things being equal, to take advantage of the federal safe harbor provision. It is another thing entirely to say that the legislature would have wanted the availability of the safe harbor provision to trump any and all competing considerations, such as ensuring that every vote be counted. ${ }^{55}$ The outcome of the 2000 presidential election quite possibly turned on this aspect of the Bush decision, a rationale that is, to put it bluntly, a complete fabrication.

A separate concurring opinion joined by the Court's three most conservative members, Chief Justice Rehnquist, Justice Scalia, and Justice Thomas-an opinion that commentators plausibly have suggested was originally designed as the niajority opinion ${ }^{56}$-emphasizes a different rationale for reversing the Florida Supreme Court and terminating the manual recount. ${ }^{57}$ According to these Justices, Article II of the Constitution, which provides that state legislatures shall determine the manner of selecting presidential electors, forbids any state court interpretation of state election law that departs from the legislative design. Chief Justice Rehnquist identifies several ways in which (he believes) the Florida Supreme Court's decision ordering a statewide manual recount impermissibly distorts state election law. ${ }^{58}$

The concurring opinion charts new territory, since this provision im Article II has generated only one prior Supreme Court interpretation, which is not even directly relevant to Bush. ${ }^{59}$ To say that the concurring opinion

53. Id. at 78 (noting that "a legislative wish to take advantage of the 'safe harbor" would counsel against any construction of the Election Code that Congress might deem to be a change in the law"). Nothing in the Florida election code expresses such a "wish," and even if it did, it is hard to fathoun which statutory interpretations this insight would "counsel against," given that state courts engaging in statutory interpretation presumably always are trying to identify correctly the legislature's intention.

54. See, e.g., Gore v. Harris, 773 So. 2d 524, 528 (Fla. 2000) (Shaw, J., concurring) ("[I]n my opinion, December 12 was not a 'drop-dead' date under Florida law.").

55. Bush, 531 U.S. at 149 (Breyer, J., dissenting).

56. See, e.g., Savage \& Weinstein, supra note 23, at Al.

57. Bush, 531 U.S. at 111 (Rehnquist, C.J., concurring).

58. See infra text accompanying notes 102-103.

59. McPherson v. Blacker, 146 U.S. 1 (1892). The issue in McPherson was whether a state violated Article 11 by providing for selection of presidential electors by popular vote within electoral districts, rather than at large. The Court quite sensibly concluded that this scheme did not violate 
adopts a novel construction of Article $1 \mathrm{I}$ is, again, not necessarily to suggest that there is anything wrong with that interpretation. The relevant question is whether the interpretation, and its application, is persuasive, not whether it is novel. It is also relevant whether the interpretive principles employed in that construction are reconcilable with the general jurisprudential commitments of the Justices who embraced it. On neither of these scores does the concurring opinion pass muster.

The persuasiveness of the concurring opinion's finding of an Article II violation depends on the answer to two questions. First, should the standard by which federal courts review state court interpretations of state law be more aggressive than usual in the context of resolving presidential election contests? Second, how unreasonable were the Florida Supreme Court's interpretations of state election law in Bush? The stronger the case for aggressive review and the more unreasonable the state court's interpretations, the more persuasive is the concurring opinion's determination that Article II was violated.

As to the standard of review, Chief Justice Rehnquist begins by conceding that, "[i]n most cases, comity and respect for federalism compel us to defer to the decisions of state courts on issues of state law." ${ }^{260} \mathrm{He}$ goes on to observe, however, that because Article II explicitly empowers the state legislature to select the manner of appointing electors, and because the federal safe harbor provision applies only when the state election law was in place on the day of the election, "the text of the election law itself, and not just its interpretation by the courts of the States, takes on independent significance."61 Rehnquist does not go so far as to suggest that federal courts should engage in de novo interpretation of state election law in the context of a presidential election contest. Indeed, it would be hard to imagine Rehnquist, Scalia, and Thomas, Justices in the vanguard of the 1990s renaissance of constitutional federalism, ${ }^{62}$ subscribing to the

Article 11's injunction that state legislatures choose the manner of selecting presidential electors. The holding has essentially no relevance to Bush $v$. Gore, though dicta in the case arguably were relevant to the issue in the Court's first confrontation with the Florida election dispute. See Bush v. Palm Beach County Canvassing Board, 531 U.S. 70 (2000) (per curiam) [hereinafter Bush I]. One of the questions in Bush I was whether a state constitution could cabin a state legislature's discretion in providing for the manner of selecting presidential electors, id. at 77, and dicta in McPherson had answered that question in the negative. 146 U.S. at 25 .

60. Bush, 531 U.S. at 112 (Rehnquist, C.J., concurring). This principle is about as wellestablished as any can be. See Murdock v. Memphis, 87 U.S. (20 Wall.) 590, 635 (1875) (noting that with regard to nonfederal questions, "we must receive the decision of the state courts as conclusive"); Commissioner v. Estate of Bosch, 387 U.S. 456, 465 (1967) ("[T]he state's highest court is the best authority on its own law.").

61. Bush, 531 U.S. at 113.

62. See, e.g., United States v. Morrison, 529 U.S. 598 (2000) (restrictive reading of commerce clause and Section 5 powers); Alden v. Maine, 527 U.S. 706 (1999) (state sovereign immunity in state court); City of Boeme v. Flores, 521 U.S. 507 (1997) (restrictive reading of Section 5 power); Printz v. United States, 521 U.S. 898 (1997) (Tenth Amendment prohibition on federal commandeering of state 
proposition that federal courts owe no deference whatsoever to state court interpretations of state law, regardless of the context. Instead, the concurring opinion argues for reduced deference.

This is an odd interpretation of Article II for these conservative Justices to embrace. Justices Scalia and Thomas, and to a lesser extent Chief Justice Rehnquist, ordinarily profess a commitment to an originalist methodology of constitutional interpretation. ${ }^{63}$ Yet, they provide no evidence in Bush that the Framers of Article II intended to bolster the role of state legislatures in the selection of presidential electors by constraining state courts adjudicatimg contests arising out of presidential elections in their ability to resolve ambiguities in the meaning of state election law. Nor does the federal statute implementing Article II (and the Twelfth Amendment), enacted after the 1876 election fiasco, indicate any congressional desire to have presidential election contests adjudicated under rules different from those employed in ordinary state election contests. ${ }^{64}$

Furthermore, the concurring opinion fails to offer any functional justification for affording state legislatures federal judicial protection from their own state judiciaries. Even were Article II sensibly interpreted to offer such protection, the Florida legislature has indicated no desire to take advantage of it. That legislature adopted a unitary election code, generally applying the same election contest rules to state and federal elections. ${ }^{65}$ Indeed, the Florida legislature has shown itself perfectly capable of indicating a preference, when it has one, to avoid judicial resolution of election contests; under Florida's election code, disputes involving the election of state legislators are to be handled exclusively by the respective houses of the state legislature, not the courts. ${ }^{66}$ It is plausible to draw the negative inference that the Florida legislature intended contests involving presidential elections to be adjudicated in the state courts according to the same rules that govern state election disputes (excepting those involving state legislators). In other settings, these same Justices have emphasized the importance of freeing states from federal command with regard to the

executive officials); Semmole Tribe of Florida v. Florida, 517 U.S. 44 (1996) (state sovereign immunity in federal court under Eleventh Amendment).

63. See, e.g., Antonin Scalia, Originalism: The Lesser Evil, 57 U. CIN. L. Rev. 849 (1989); William Rehnquist, The Notion of a Living Constitution, 54 TEx. L. REv. 693 (1976); McIntyre v. Ohio Elections Comm'n, 514 U.S. 334, 370-71 (1995) (Thomas, J., concurring); id. at 372 (Scalia, J., dissenting).

64. Electoral Count Act of 1887, 24 Stat. 373, 3 U.S.C. $\$ 5$ (providing a safe harbor from congressional challenge where a "state shall have provided, by laws enacted prior to [election day], for its final determination of any controversy or contest concerning the appointment of ... [electors] . . . by judicial or other methods").

65. Bush, 531 U.S. at 124 (Stevens, J., dissenting).

66. Fla. Stat. ANN. ch. 102.168 (1982 \& Supp. 2000). 
structuring of their own governmental processes. ${ }^{67}$ Thus, it seems strange that the concurring opinion would not require a clearer statenient fron the constitutional text or the Framers' original understanding before inferring a constitutional command to federalize the allocation of state decisionmaking authority in the context of selecting presidential electors.

Offering neither originalist nor functionalist support for their interpretation, the concurring Justices rely entirely on the text of Article II, specifically its reference to state "legislatures" directing the manner of choosing presidential electors. This spare textual reference simply does not bear the weight the concurrence ascribes to it. Article I of the Constitution declares that "[a]11 legislative Powers herein granted shall be vested in a Congress of the United States." language precludes judicial interpretation of congressional statutes. Indeed, since I935 the Court never has held that this constitutional mandate that Congress exercise "[a]1l legislative power" precludes Congress from enacting vague (meaningless) statutes that essentially delegate the lawmaking power to administrative agencies and to courts. ${ }^{69}$ Indeed, sonie members of the conservative Bush plurality are among the biggest proponents of the Chevron doctrine, whieh requires federal courts to defer to "reasonable" agency interpretations of statutes, notwithstanding the Article I injunction that Congress "legislat[e]."70 In Bush, Chief Justice Rehnquist does not explain why broad-ranging judicial and administrative interpretation of federal statutes is permissible in spite of Article I's requirement that "[a]11 legislative powers" be vested in "Congress," but Article II's injunction that state "[1]egislatures" direct the manner of appointing presidential electors forbids state courts fron 1 engaging in ordinary statutory interpretation of state election law. Thus, not only does the plurality offer no originalist or functionalist justification for its Article II argument, but its bare textualist claim is almost laughable. It appears likely that nobody in the first two hundred years of the Republic ever dreamed of this interpretation of Article II. This probably explains why neither the Bush lawyers, nor the

67. Cf. Gregory v. Ashcroft, 501 U.S. 452,460 (1991) (requiring an "unmistakably clear" statement by Congress before construing a federal antidiscrimination law to apply to a state's judiciary because it is "[t]hrough the structure of its government ... [that] a State defines itself as a sovereign").

68. U.S. CoNST., Art. $1, \S 1$.

69. The last Supreme Court decisions invalidating federal legislation on nondelegation grounds were Panama Refining Co. v. Ryan, 293 U.S. 288 (1935), and A.L.A. Schechter Poultry Corp. v. United States, 295 U.S. 495 (1935). For a modern illustration of how defunct the nondelegation doctrine is, see Mistretta v. United States, 488 U.S. 361 (1989). Last term's decision in Whitman v. American Trucking Ass'ns, Inc., 531 U.S. 457 (2001), appears to confirm that the doctrine is moribund. In all fairness, at least the Chief Justice is on record as favoring a reinvigoration of this doctrine. See, e.g., Industrial Union Dep't v. American Petroleum Institute, 448 U.S. 607, 672-76 (1980) (Rehnquist, J., concurring).

70. See, e.g., NLRB v. United Food \& Commercial Workers Union, 484 U.S. 112, 133-34 (1987) (Scalia, J., concurring, with Rehnquist, C.J.); INS v. Cardoza-Fonseca, 480 U.S. 421, 453-55 (1987) (Scalia, J., concurring); Antonin Sealia, Judicial Deference to Administrative Interpretations of Law, 1989 DUKE L.J. 5 I I. 
Justices themselves, thought to raise the Article II ground when the first Florida Supreme Court decision was appealed to the High Court, focusing instead on the palpably erroneous federal statutory argument. ${ }^{71}$

Chief Justice Rehnquist seeks to bolster the flimsy Article II argument by observing that there are other "areas in which the Constitution requires this Court to undertake an imdependent, if still deferential, analysis of state law." 72 The Chief Justice plainly is correct about the existence of instances in which the Supreme Court has rejected state court interpretations of state law. Federal rights often become entwined with questions of state law, and state judiciaries would be able to obstruct implementation of those rights if their own interpretations of state law were immune from federal review. ${ }^{73}$ Consider a few examples. State law determines whether a contract exists, which is a necessary predicate for a violation of Article I, Section 10, which forbids state impairment of the obligation of contract. ${ }^{74}$ Similarly, state law determines whether a property right exists, which is a necessary predicate for the finding of an uncompensated taking, in violation of the Fifth and Fourteenth Amendments. ${ }^{75}$ Whether retroactive criminal punishment has been imposed, in violation of the Ex Post Facto or Due Process Clauses, depends on whether state criminal law has changed since the defendant committed the alleged transgression, which turns partly on a determination of what state law was before the defendant acted. ${ }^{76}$ Finally, because the Supreme Court will not decide a federal question when "adequate and imdependent" state grounds exist to sustain a state court ruling, vindication of federal rights that are raised in state court proceedings depends on compliance with state procedural law. ${ }^{77}$ The adequacy of the

71. See David A. Strauss, Bush v. Gore: What Were They Thinhing?, 68 U. CHI. L. REv. 737, 744-46 (2001).

72. Bush, 531 U.S. at 114,115 \& n.l (Rehnquist, C.J., concurring) (citing NAACP v. Alabama ex rel. Patterson, 357 U.S. 449 (1958), Bouie v. City of Columbia, 378 U.S. 347 (1964), and Fairfax's Devisee v. Hunter's Lessee, 7 Cranch 603 (1813)).

73. See, e.g., Peter W. Low \& John C. Jefrries, Jr., Federal Courts and the Law of Federal-State ReLations 82 (4th ed. 1998) ("II]f there were no limits on the freedom of state courts to determine whether a contract had been created and the nature of its obligations, the federal limitation might be easily evaded.").

74. See, e.g., Indiana ex rel. Anderson v. Brand, 303 U.S. 95, 100 (1938). The Court stated On such a question [of whether there is a contract], one primarily of state law, we accord respectful consideration and great weight to the views of the State's highest court but, in order that the constitutional mandate may not become a dead letter, we are bound to decide for ourselves whether a contract was made, what are its terms and conditions, and whether the State has, by later legislation, impaired its obligation.

Id. at 100 .

75. See, e.g., Lucas v. South Carolina Coastal Council, 505 U.S. 1003, 1032 n.18 (1992) (noting that the Court will defer only to "an objectively reasonable applieation of relevant precedents" defining the property right).

76. See, e.g., Bouie v. City of Columbia, 378 U.S. 347 (1964).

77. See, e.g., Murdock v. Memphis, 87 U.S. (20 Wall.) 590 (1875). 
state ground of decision depends partly on its not having been invented post hoc to defeat the posited federal right. ${ }^{78}$

Thus, the concurring opinion correctly observed that the Supreine Court occasionally has rejected state court interpretations of state law in order to protect federal rights. Yet the rule generated by these cases seems to be one requiring evidence of bad faith by the state courts in their interpretation of state law. All three of the Supreme Court precedents cited by the concurring opinion on this score involved situations where state courts had manifested, beyond a shadow of a doubt, the willingness to defy federal law. ${ }^{79} \mathrm{~A}$ closer look at the two modern cases invoked by the concurring opinion reveals how little support they provide for federal court intervention in Bush v. Gore. ${ }^{80}$

In NAACP v. Alabama, ${ }^{81}$ the Supreme Court ruled that the NAACP had a First Amendment right to refuse to disclose its membership lists to Alabama authorities. Before reaching the merits of the case, though, the Justices first had to decide whether the federal constitutional claim was procedurally barred. The Alabama Supreme Court had refused to consider the First Amendment claim on its merits, because of the Association's failure to follow the correct procedural path for securing state supreme court review of its contempt citation for refusing to disclose its meinbership lists. Specifically, the state court ruled that the NAACP should have sought a writ of prohibition rather than a writ of mandamus. It is inconceivable that the Justices' view of the case, both on the merits and on the alleged state procedural default, was uninfluenced by their knowledge that the state of Alabama, including its jurists, were engaged in a project of massive resistance toward Brown v. Board of Education, ${ }^{82}$ a fundamental part of which involved shutting down the NAACP's operations in the state. ${ }^{83}$ Yet even setting aside this extrinsic basis for questioning the good faith of the state

78. See, e.g., NAACP v. Alabama ex rel. Patterson, 357 U.S. 449 (1958); see generally Broad River Power Co. v. South Carolina, 281 U.S. 537, 540-41 (1930) ("II]f there is no evasion of the constitutional issue, and the non-federal ground of decision has fair support, this Court will not inquire whether the rule applied by the state court is right or wrong, or substitute its view of what should be deemed the better rule, for that of the state court.") (citations omitted).

79. Bush, 531 U.S. at 140 (Ginsburg, J., dissenting) (noting that the three cases invoked by the concurring opinion were "embedded in historical contexts hardly comparable to the situation here").

80. The third case, as Justice Ginsburg notes in dissent, involved the Revolutionary era conflict between southern state legislation confiscating Tory lands and federal treaties seeking to curtail confiscation. That conflict led southern state courts to engage in efforts at nullification no more subtle than those undertaken by their counterparts in the civil rights era. Bush, 531 U.S. at 139-40 (Ginsburg, J., dissenting) (citing Fairfax's Devisee v. Hunter's Lessee, 7 Cranch 603 (1813); Martin v. Hunter's Lessee, 1 Wheat. 304 (1816)).

81. NAACP v. Alabama ex rel. Patterson, 357 U.S. 449 (1958).

82. See Numan Bartley, The Rise of Massive Resistance (1969).

83. See Walter Murphy, The South Counterattacks: The Anti-NAACP Laws, 12 W. PoL. Q. 371 (1959). On background to NAACP v. Alabama, see MaRK V. TuSHNET, MAKING Civil Rights LAw 284-89 (1994); Robert Jerome Glennon, The Jurisdictional Legacy of the Civil Rights Movement, 61 TENN. L. Rev. 869, 887-900 (1994). 
court justices in $N A A C P,{ }^{84}$ the Supreme Court was able to identify no fewer than a half dozen prior Alabama Supreme Court decisions that had rejected precisely the procedural distinction relied upon by that court in $N A A C P$ to justify its refusal to reach the merits of the First Amendment claim. ${ }^{85}$ Incredibly, the state supreme court, at an earlier stage of these same proceedings, had directed the NAACP's lawyers to seek appellate review via the very procedural route (a writ of mandamus) that the state justices later determined to constitute a procedural default. ${ }^{86}$ In other civil rights era cases where the Supreme Court likewise declined to permit state procedural defaults to block federal review of constitutional claims, the Justices also were able to poimt to earlier state precedents that directly contravened the state court's finding of a procedural default in the case under review. ${ }^{87}$

Notwithstanding Chief Justice Rehnquist's claim that precedents like $N A A C P$ v. Alabama were "precisely parallel" to $B u s h,{ }^{88}$ he failed to identify anything even remotely similar in Florida case law that would warrant the conclusion that the Florida Supreme Court was departing from established precedent. Without expressly saying so, the conservative Justices implied that the Florida Supreme Court's statutory interpretations in Bush were entitled to no greater deference in federal court than those of renegade White supremacist nullifiers during the civil rights era. ${ }^{89}$ One might have expected that these Justices would offer some factual predicate to justify this extraordinary, albeit implicit, aspersion on the integrity of state court jurists, ${ }^{90}$ but they did not.

The other civil rights era decision invoked as precedent in Bush for upsetting a state court's interpretation of state law was Bouie v. City of

84. Most of the other leading cases rejecting the adequacy of state procedural grounds for denying federal rights also involve southern states obstructing the civil rights movement. See, e.g., Barr v. City of Columbia, 378 U.S. 146 (1964); NAACP v. Alabama ex rel. Flowers, 377 U.S. 288 (1964); Shuttlesworth v. City of Alabama, 376 U.S. 339 (1964); Wright v. Georgia, 373 U.S. 284 (1963); see also Low \& JEFFrIES, supra note 73, at 109 ("It is no coincidence that many such cases arose in the civil rights litigation in the 1960s."); Glennon, supra note 83 , at 887-900.

85. 357 U.S. at 456 (concluding that "[w]e are unable to reconcile the procedural holding of the Alabama Supreme Court in the present case with its past unambiguous holdings").

86. Id. at 458 .

87. See, e.g., NAACP v. Alabama ex rel. Flowers, 377 U.S. 288, 297-300 (1964); Barr v. City of Columbia, 378 U.S. 146, 149 (1964); see also Indiana ex rel. Anderson v. Brand, 303 U.S. 95, 105-07 (1938) (rejecting a state court's determination of whether a contract existed because it conflicted with numerous earlier decisions of that court).

88. Bush, 531 U.S. at 115 (Rehnquist, C.J., concurring).

89. Bush, 531 U.S. at 128 (Stevens, J., dissenting) (noting that what must underlie the concurring Justices' unwillingness to defer to the state court's interpretation of state law "is an unstated lack of confidence in the impartiality and capacity of the state judges who would make the critical decisions if the vote count were to proceed").

90. Id at 141 (Ginsburg, J., dissenting) (objecting that the Florida Supreme Court ought not be "be bracketed with state high courts of the Jim Crow South"). 
Columbia. ${ }^{91}$ That case is equally weak support for the Article II rationale in Bush, but for a different reason. In Bouie, the question was whether it violated the Due Process Clause to convict sit-in demonstrators under a criminal trespass statute that barred "entry on lands of another after notice prohibiting same" 92 when the protestors had been commanded to depart, but not warned against entering in the first place. The Supreme Court ruled that for the state supreme court to interpret this statute to cover refusals to leave as well as forbidden entries "unforeseeably and retroactively expanded" its meaning. ${ }^{93}$ In the process of so ruling, the Court had to reject the state court's implicit determination that the criminal trespass statute always had been construed this way. The Justices were able to cite only extraneous dicta, not actual holdings, in support of their refutation of the state court's interpretation of state law. ${ }^{94}$

The Bouie Court's extraordinarily stringent interpretation of the notice requirement imposed by the Due Process Clause, ${ }^{95}$ and its unwillingness to defer to a state court's ostensibly sensible construction of a state statute, can be understood only in the context of the times. Between 1960 and 1964 , the Supreme Court confronted dozens of cases in which sit-in demonstrators were prosecuted for breach of the peace, trespass, and sundry other offenses. ${ }^{96}$ The Justices were disinclined to affirm the criminal convictions of persons with whose racial protest they generally sympathized. Yet, they also were unwilling to vindicate the protesters' principal legal claim that the state action necessary for an equal protection violation was present when the state simply was enforcing background common law property rules.$^{97}$ Instead, the Justices identified a wide range of imaginative (specious) grounds for reversing the convictions without reaching the fundamental constitutional question. ${ }^{98}$

By the time Bouie arrived on the Court's docket, the 1964 Civil Rights Act, which would moot the state action issue by creating a federal statutory prohibition on race discrimination in places of public

91. 378 U.S. 347 (1964).

92. Id. at 349 n.l (reproducing the statute).

93. Id. at 352 .

94. Id. at 356-57.

95. See, e.g., id. at 363, 367 (Black, J., dissenting) (noting that nobody could have been misled by this construction of the statute).

96. See, e.g., Thomas P. Lewis, The Sit-in Cases: Great Expectations, 1963 Sur. CT. Rev. 101; Monrad G. Paulsen, The Sit-in Cases of 1964: "But Answer Came There None," 1964 SuP. CT. Rev. 137.

97. I have described some of the internal deliberations in the sit-in cases, with citations to the original documents, in Michael Klarman, An Interpretive History of Modern Equal Protection, 90 MiCH. L. REv. 213, 272-76 (1991).

98. See, e.g., Griffin v. Maryland, 378 U.S. 130 (1964) (reversing a trespass conviction on the ground that an arrest by a park employee who had been deputized as a sheriff constituted state action); Garner v. Louisiana, 368 U.S. 157 (1961) (revcrsing a disburbing-the-peace conviction on the due process ground of total absence of evidence). 
accommodation, was finally nearing passage, after the longest filibuster in the history of the United States Senate. ${ }^{99}$ In that setting, the Juștices understandably were reluctant to affirm, for the very first time, the conviction of a sit-in demonstrator. Thus the Court "invented" a due process objection to Bouie's conviction, rejecting the state court's view that the state criminal trespass statute always had forbidden refusals to depart after notice to leave, and holding that to interpret the provision this way now represented an unforeseeable expansion of the statute, in violation of the Due Process Clause. Nobody who teaches criminal law would recognize this conception of what due process notice requires. ${ }^{100}$ Leading criminal law casebooks treat Bouie as bad law, a case that can be accounted for only by the Justices' political sympathies for the civil rights movement. ${ }^{101}$ Thus, the only legal principle that Bouie genuinely stands for is that sometimes the Supreme Court, for political reasons, will decide cases in a lawless fashion. In one sense, then, though not the one the conservative Justices intended, Bouie was the perfect case for them to cite in Bush.

After laying the groundwork for reducing the deference owed to the state court's interpretations of Florida law, the concurring opinion proceeds to enumerate several ways in which that court's interpretations were said to have violated the legislature's design. The concurring Justices raised the following objections to the state supreme court decision in $B u s h^{102}$ : it deprived the secretary of state's certification of the election results of "virtually all legal consequence"; ${ }^{103}$ it engaged in de novo review of the local canvassing boards' decisions whether to conduct manual recounts after the certification deadline; it eliminated the statutory grant of discretion to the Secretary of State with regard to waiving the certification deadline by ordering the inclusion in the certification of all recounts completed during the contest phase; it unreasonably construed the contest provision requiring that "legal votes" not be rejected to require the counting of "improperly marked ballots"; it refused to defer to the Secretary of State's reasonable interpretations of state election law, as required by statute; and it unreasonably construed the statutory grant to state courts of the power to

99. Hugh Davis Graham, The Civil Rights Era: Origins and Devglopment of National PoliCY, 1960-1972, at 151 (1990).

100. See, e.g., John Calvin Jeffries, Jr., Legality, Vagueness, and the Construction of Penal Statutes, 71 VA. L. REv. 189, 211 (1985) (arguing that the "core concept of notice as a requirement of faimess to individuals" focuses on "whether the ordinary and ordinarily law-abiding individual would have received some signal that his or her conduct risked violation of the penal law").

101. See, e.g., Peter low et al., Criminal Law: Cases and Materials 100, 106 (2d ed. 1986) (speculating that "the Court's application of [fair notice] principles to the Bouie facts was solnewhat more rigid than would have been the case if a more ordinary trespass was involved" and noting that "the Supreme Court itself understands the context of Bouie as qualifying its message,... [since] ... Bouie has not becoine a substantial constraint on the interpretation of ambiguities in subsequently construed federal criminal statutes").

102. Bush, 53I U.S. at 113-23 (Rehnquist, C.J., concurring).

103. Id. at 118 . 
issue "appropriate relief" in contest actions to include a statewide inanual recount that could not possibly be coinpleted in time to realize the state legislature's "wish" to take advantage of the federal safe harbor provision.

It is fair to say that the protest and contest provisions of Florida election law are characterized by significant ambiguity, which for the most part never has been clarified by the Florida courts-unsurprisingly, since the contest provisions were substantially overhauled in $1999 .{ }^{104}$ On many of the statutory interpretation issues raised in Bush, reasonable people surely might differ. ${ }^{105}$ Yet none of the Florida court's interpretations are particularly "peculiar," 106 and certainly none of them qualifies as "absurd," 107 which is how the concurring opinion characterizes them. Florida election law clearly contemplates a contest to certified election results. The substantive standard that must be established for the contest to proceed is, in relevant part, the "rejection of a number of legal votes sufficient to change or place in doubt the result of the election." 108 Given the closeness of the certified presidential election result in Florida, a margin of 537 votes for Bush, there is no doubt that the number of undervotes (estimated at 60,000 ) was sufficient to "place in doubt" the election result. The only question was whether undervotes qualify as "legal votes." This was a question of first impression for the Florida Supreme Court. The state jurists determined that ballots that clearly express the intent of a voter, but that were marked in such a way that the voting machines could not read them, qualify as "legal."109 The concurring opinion calls this conclusion "absurd," yet it is consistent with the way Florida courts historically have defined legal votes ${ }^{110}$ with explicit language in the Florida election code requiring that

104. On the contrast between the new and the old contest provisions, see Gore v. Harris, 772 So. $2 d 1243,1251$ n.9 (Fla. 2000).

105. The dissenting opinions of Justices Souter and Breyer ably demonstrate how the Florida court's resolutions of all the relevant statutory ambiguities were at least reasonable. Bush, 531 U.S. at 130-33 (Souter, J., dissenting); id. at 149-52 (Breyer, J., dissenting). Several of the points made in this and the following paragraphs are also made in those dissenting opinions. For a strong statement of the contrary view-that the Florida Supreme Court "butchered" the state election statute, see Richard A. Posner, Florida 2000: A Legal and Statistical Analysis of the Election Deadlock and the Ensuing Litigation, 2000 SuP. CT. REV. 1.

106. Bush, 531 U.S. at 120 (Rehnquist, C.J., concurring).

107. Id. at 119.

108. Fla. Stat. ANN. ch. 102.168(3)(c) (2000) (1982 \& Supp. 2000).

109. Gore v. Harris, 772 So. $2 \mathrm{~d}$ at $1256-57$.

110. See, e.g., Boardman v. Esteva, 323 So. 2d 259, 267 (Fla. 1975) (denying, in the context of a challenge to absentee ballots, that there is any "magic in the statutory requirements," and insisting that the "important" question is whether "the will of the people was effected"); State ex rel. Carpenter v. Barber, 198 So. 49, 50-51 (Fla. 1940) (concluding that a ballot shall be counted "if the will and intention of the voter can be determined," even if the voter did not follow the instructions for marking the ballot); Wiggins v. State ex rel. Drane, 144 So. 2d 62, 63 (Fla. 1932) (holding that ballots that "clearly indicate the choice of the voter" must be counted, even if "irregular"); Darby v. State ex rel. McCollough, 75 So. 411, 412 (Fla. 1917) (per curiam) ("Where a ballot is so marked as to plainly indicate the voter's choice and intent in placing his marks thereon, it should be counted as marked unless some positive provision of law would be thereby violated."). 
the "intent of the voter" be ascertained with regard to damaged and defective ballots, ${ }^{111}$ and with the interpretation of numerous other state supreme courts. ${ }^{112}$ Nor is it clear that the Florida Supreme Court owed any particular deference to the Secretary of State's contrary interpretation, given the political nature of her position, the absence of any obvious agency "expertise" that would entitle her interpretation to deference, the fact that her interpretation was post hoc rather than a product of ex ante rulemaking, and the generally uncertain standard of judicial deference to agency legal interpretations called for by Florida administrative law. ${ }^{13}$

111. Fla. StAT. ANN. ch. 101.5614 (5) (1982 \& Supp. 2000) (providing that no ballot shall be disregarded "if there is a clear indication of the intent of the voter as determined by the canvassing board"); see also id. $\$ 102.166$ (7) (specifying procedures for a manual recount, which include counting teams and, if necessary, county canvassing boards seeking "to determine a voter's intent").

112. See, e.g., In re Election of U.S. Representative for Second Congressional Dist., 653 A.2d 79, 90-91 (Conn. 1994) (rejecting the view that legal votes are only those complying strictly with the ballot instructions and instead counting all ballots upon which "the intent of the voter" is apparent "in light of all of the available evidence disclosed by the ballot'); Duffy v. Mortensen, 497 N.W.2d 437, 439 (S.D. 1993) (holding that a punch card ballot with two corners of the chad detached must be counted, since the voter's intent could be discemed, and "the policy of the state is to count each person's vote in an effort to determine the true and actual intent of the voters"); Pullen v. Mulligan, 561 N.E.2d 585, 611 (IIl. 1990) (holding that "voters should not be disfranchised where their intent may be ascertained with reasonable certainty, simply because the chad they punched did not completely dislodge from the ballot"); Fischer v. Stout, 741 P.2d 217, 221 (Alaska 1987) (holding that punch-card ballots marked entirely in pen and pencil are legal votes, 'because they provided clear evidence of the voters' intent'); Wright v. Gettinger, 428 N.E.2d 1212, 1225 (Ind. 1981) (affirming trial court's judgment that ballots with "hanging chads" could be counted, since "the intention of the voter could clearly be discerned"); McCavitt v. Registrar of Voters of Brockton, 434 N.E.2d 620, 624-25 (Mass. 1982) (holding that the court must ascertain the intent of the voters with regard to punch card ballots that have not been punched through sufficiently for the machine to count them); Escalante v. City of Hermosa Bcach, 241 Cal. Rptr. 199, 201-03 (Cal. App. 1987).

113. For a concise summary of the conflicting approaches that Florida courts have taken on the question of how much deference courts owe to agency legal interpretations, see David M. Greenbaum \& Lawrence E. Sellers, Jr., 1999 Amendments to the Florida Administrative Procedure Act: Phantom Menace or Much Ado About Nothing?, 27 FLA. ST. L. REv. 499, 522-24 (2000). Compare Krivanek v. Take Back Tampa Political Comm., 625 So. 2d 840, 844 (Fla. 1993) ("although not binding judicial precedent, advisory opinions of affected agency heads are persuasive authority and, if the construction of law in those opinions is reasonable, they are entitled to grcat weight in construing the law as applied to that affected agency of government'), and State Dep't of Health \& Rehabilitative Servs. v. Framat Realty, Inc., 407 So. 2d 238, 242 (Fla. App. 1981) (according a "most weighty presumption of validity" to agency rulemaking), with Tampa Electric Co. v. Garcia, 767 So. 2d 428 (Fla. 2000) (per curiam) (showing no deference to an agency's legal interpretation), and Legal Envtl. Assistance Found. v. Board of County Comm'ss, 642 So. 2d 1081, 1083-84 (Fla. 1994) (refusing to defer to an "unreasonable" interpretation); see also Darby v. State ex rel. McCollough, 75 So. 411 (Fla. 1917) (showing no deference to local election officials' interpretation of what counts as a legal vote). For the rule that only interpretations implicating an agency's expertise warrant deference, see, for example, Zopf v. Singletary, 686 So. 2d 680, 682 (Fla. App. 1996); Board of Trustees. v. Dep't of Mgmt. Servs., 651 So. 2d 170, 173 (Fla. App. 1995). For the rulemaking requirement, see FLA. STAT. ANN. ch. 120.54 (1995 \& Supp. 2001). For the willingness of Florida courts to show greater deference to agency legal interpretations that flow from rulemaking, as opposed to post hoc adjudication, see, for example, Florida Cities Water Co. v. Florida Pub. Serv. Comm'n, 384 So. 2d 1280, 1281 (Fla. 1980); AnheuserBusch, Inc. v. Dep't of Bus. Regulation, 393 So. 1177, 1182 (Fla. App. 1981). I am grateful to Jim Rossi for directing me to relevant sources and for helping to clarify Florida administrative law for me. 
The contest provisions of the Florida election code do not disclose what level of deference is owed to the Secretary of State's certification of election results, or to local canvassing boards' decisions not to conduct manual recounts. Since the very purpose of an election contest is to challenge the certification, it makes no sense to have a contest provision while deferring entirely to the certification. The statutory standard for a contest to proceed, "rejection of a number of legal votes sufficient to change or place in doubt the results of the election," does not indicate that any deference at all is owed to the decisions of administrative officials. Perhaps de novo review is not the most sensible way of structuring an election contest scheme, but it is perfectly consistent with the statutory language, which the concurring opinion emphasizes is entitled to special weight in light of Article II concerns. ${ }^{114}$ Nor does it contravene any Florida Supreme Court precedent, since that court never before had interpreted the amended contest provisions. A Florida intermediate appellate court, construing the old contest provision, had ruled that the same deference explicitly granted by statute to local canvassing boards with regard to conducting manual recounts during the protest phase should apply during the contest phase, ${ }^{115}$ but that ruling is not precedent for the state supreme court. Moreover, to overrule in the contest phase of the proceedings a local canvassing board's discretionary judgment during the protest phase not to conduct a manual recount does not nullify the statutory grant of discretion; rather, it restricts its force to elections that are not so close at the state level as to raise a doubt whether uncounted lawful votes might change the election outcome. ${ }^{116}$ Thus, the Florida Supreme Court's decision to engage in de novo review of Vice President Gore's request for manual recounts is consistent with the statutory contest language, not inconsistent with any binding Florida precedent, and reconcilable with a statutory grant of discretion to local canvassing boards not to conduct manual recounts at the protest phase of election proceedings. In what alternate universe does such an interpretation of Florida election law qualify as "absurd"?

Having found the statutory contest standard satisfied, the Florida Supreme Court ordered a statewide manual recount, notwithstanding the shortness of time. The court relied on the statutory provision authorizing

114. It is ironic, given the concurring opinion's emphasis on the text of the Florida election code, that it was the Bush camp arguing against a literal, and in favor of a holistic, reading of the statute. See, e.g., Brief for Petitioners at 20, Bush (No. 00-949) (noting that the Florida legislature "enacted a carefully crafted statutory scheme"); id. at 23 (arguing that the Florida Supreme Court's decision "is nothing less than the evisceration of the intemal coherence of the legislature's desigu").

115. Broward County Canvassing Board v. Hogan, 607 So. 2d 508 (Fla. Ct. App. 1992) (per curiam).

116. Gore v. Harris, 772 So. 2d at 1270-71 (Harding, J., dissenting) (noting that the "abuse of discretion" standard applicable at the protest phase does not apply during the contest phase); Bush, 531 U.S. at I51-52 (Breyer, J., dissenting). 
courts to order "any relief appropriate"117 once the threshold requirement for an election contest had been satisfied. The concurring opinion states that this reading of "appropriate relief" cannot be reconciled with the legislature's "wish" to take advantage of the federal safe harbor provision. Yet, as we have seen, the legislature expressed no such wish, and even if it had, reading Florida election law to elevate that wish over all competing considerations would be nonsensical. ${ }^{118}$ The Florida Supreme Court ordered the statewide manual recount on December 8. In all likelihood, that recount would have been completed by December $12^{119}$ had the Supreme Court not stayed it the morning it began (December 9). ${ }^{120}$ The recount almost certainly would have been completed by December 18 , the date by which Florida electors had to be appoimted in order to participate in the electoral college balloting. There is nothing odd about construing "any relief appropriate" to mclude a statewide manual recount that probably could have been completed in time to avoid jeopardizing Florida's participation in the electoral college vote. ${ }^{121}$

Finally, the Gore team not only had the plain meaning of the statute on its side, but also the plain tenor of Florida election law precedent. While the specific statutory interpretation questions raised by the election contest were not resolved by prior precedent, the one clear principle to be derived from Florida election cases is that safeguarding the right to vote and ascertaining the will of the voter trump more technical questions of compliance with legal formality. Numerous Florida court decisions have embraced this proposition. ${ }^{122}$ In light of this background interpretive principle, plainly established by Florida precedent, the Florida Supreme Court's ruling that

117. Fla. Stat. AnN. ch. 102.168(8) (1982 \& Supp. 2000).

118. See supra text accompanying notes 50-55.

119. See, e.g., Editorial, Another Roller Coaster Day, WASH. Post, Dec. 10, 2000, at B6 (noting that the manual recounts were "proceeding relatively smoothly and quickly" before the Supreme Court stayed them).

120. Bush v. Gore, 531 U.S. 1048 (2000).

121. The concurring opinion notes that even if the manual recount could have been completed by December 12, "the inevitable legal challenges and ensuing appeals to the Supreme Court of Florida and petitions for certiorari to this Court ... could not possibly be completed by that date." Bush, 531 U.S. at 121 (Rehnquist, C.J., concurring). It is not obvious that this is true, especially since the relevant date is December 18, not December 12. But even if it were true, it is not obvious why a completed manual recount with uncompleted judicial challenges ought not to be preferred to a machine count that clearly missed thousands of ballots on which the voters' intention could be discemed.

122. See, e.g., Krivanek v. Take Back Tampa Political Comm., 625 So. 2d 840, 844 (Fla. 1993) ("election laws should generally be liberally construed in favor of an elector"); State ex rel. Chappell v. Martinez, 536 So. 2d 1007, 1008 (Fla. 1988) (noting that "the object of holding an election" is "the electorate's effecting its will through its balloting, not the hyper-technical compliance with statutes"); Boardman v. Esteva, 323 So. 2d 259, 263, 269 (Fla. 1975) (noting that "the right of a citizen to vote" is more important than "unyielding adherence to statutory scripture" and "that the primary consideration in an election contest is whether the will of the people has been effected"); State ex rel. Carpenter v. Barber, 198 So. 49, 51 (Fla. 1940) ("It is the intention of the law to obtain an honest expression of the will or desire of the voter."). 
presidential undervotes must be examined to ascertain, wherever possible, the actual intent of the voters was entirely unexceptionable. The barrage of criticism leveled by Republican politicos against manual recounts, ${ }^{123}$ which was slyly endorsed by the concurring opinion, ${ }^{124}$ was in fact a lawless refusal to abide by either explicit statutory language authorizing such recounts ${ }^{125}$ or abundant Florida judicial precedent endorsing the principle that ascertaining the actual intent of voters is the paramount objective of courts adjudicating election controversies. ${ }^{126}$

Reasonable people certainly can disagree where to draw the line between a inerely mistaken interpretation and a manifestly unreasonable one. Moreover, degrees of unreasonableness are notoriously difficult to quantify or otherwise measure objectively. Perhaps, in light of these considerations, it was inevitable that Republican Justices, like so many Republican politicians and voters, would conclude that the Florida Supreme Court was "stealing" the election from George W. Bush, ${ }^{127}$ and thus that its statutory

123. See, e.g., Dexter Filkins, Counting the Vote: Manual Counts, N.Y. Times, Nov. 16, 2000, at A32 (quoting James Baker criticizing manual recounts because they "present[] tremendous opportunities for human error and indeed for the possibility of mischief'); Edward Walsh, Bracing for Court Showdown, WASH. POST, Nov. 20, 2000, at A1 (quoting criticism of hand recounts by Montana Governor Mark Racicot); Editorial, Scared of Florida Count, AtLANTA J. \& Const., Nov. 21, 2000, at $18 \mathrm{~A}$ (describing Republicans' assault on manual recounts as "distorting," "miscounting," and "untrustworthy"); see also Thomas L. Friedman, Can Gore Ever Win?, N.Y. TIMEs, Nov. 21, 2000, at A25, reprinted in BuSH V. GORE, supra note 20, at 187, 188 (noting the "wild, unsubstantiated allegations that the hand counters are engaged in fraud" being made by the Bush camp).

124. Bush, 531 U.S. at 121 (Rehnquist, C.J., concurring) (noting that the manual recount of undervotes was "a search for elusive--perhaps delusive-certainty").

125. Fla. Stat. ANN. ch. 102.166 (4)(c) (1982 \& Supp. 2000); §102.166(5); see Michael W. McConnell, Supremely Ill-Judged, WALl ST. J., Nov. 24, 2000, at A16, reprinted in BuSH v. GorE, supra note 20, at 198, 199 ("Despite their high potential for arbitrariness and cven fraud, manual recounts, like deadlines, are a feature of Florida law.").

126. See supra note 122.

127. See, e.g., David Tell, The Bush Victory, WKLy. Standard, Dec. 25, 2000, at 9 (criticizing the Florida Supreme Court decision as "ridiculous" and "ghastly"); Nelson Lund, An Act of Courage, WKLY. STANDARD, Dec. 25, 2000, at 19 (accusing the Florida Supreme Court of "violat[ing] the Constitution" and blaming it for forcing the Supreme Court to intervene); Robert F. Nagel, From U.S. v. Nixon to Bush v. Gore, WKLY. STANDARD, Dec. 25, 2000, at 20 (calling the Florida Supreme Court decision "stunning" and a product of "intellectual anarchy"); Michael S. Greve, The Real Division in the Court, WKLY. STANDARD, Dec. 25, 2000, at 28 (noting some doubt as to whether "repeated judicial attempts to stack the deck in a presidential election do not compare to the moral scandal of Jim Crow"); Krauthammer, supra note 23, at A41 (blaming a "rogue state supreme court," which in "an astonishing burst of willfulness," created a "constitutional crisis" because of its "mission" to defeat George W. Bush); Matthew Vita \& Juliet Eilperin, Congress Braces for Battle over Electoral Votes, WASH. POST, Nov. 22, 2000, at A19 (quoting House Majority Whip Tom DeLay accusing the Democratic Party of "prosecuting a war to reverse the results of a fair, free election by any means necessary" and calling the Florida Supreme Court decision "a blatant and extraordinary abuse of judicial power"); Eiric Pianin \& Helen Dewar, Congress Sits on Political Powder Keg, WASH. Post, Dec. 10, 2000, at A31 (noting that DeLay and other congressional Republicans have accused Democrats and Florida's Supreme Court "of an effort to steal the election from Bush"). Indeed, the conservative Justices defended their involvement by implicitly blaming Gore for tuming to the courts in the first place. Bush, 531 U.S. at 111 ("None are more conscious of the vital limits on judicial authority than are the Members of this Court.... When 
interpretations were entitled to no more deference than those of the Jim Crow state courts that had manifested a willingness to lie and cheat in order to nulhify Brown and obstruct the civil rights moveinent. It is impossible to disprove conclusively these Republican accusations, especially since the genuine indeterminacy of Florida election law probably inade it inevitable that the partisan preferences of the Florida court's Deinocratic justices would influence their statutory interpretations in favor of $\mathrm{Al} \mathrm{Gore.}{ }^{128}$ Yet, permitting partisan considerations to influence the resolution of genuine legal ambiguity is not equivalent to "stealing" an election. It is almost impossible to imagine Rehnquist, Scalia, and Thomas concluding that these particular state court interpretations of state law were "absurd" in any context other than the one in which George W. Bush's election to the presidency hung in the balance. ${ }^{129}$ Indeed, in other settings, these three Justices have insisted that federal courts should defer even to state court interpretations of federal law unless "patently unreasonable."130 It takes little imagination to picture the impassioned-indeed, characteristically vitriolic-assault on judicial activism and federal overreaching that Justice Scalia might have penned had the candidates been reversed and it was $\mathrm{Al}$ Gore asking the United States Supreme Court to rcsolve a presidential election contest by repudiating a state court's interpretation of state law. ${ }^{131}$

\section{II \\ LONG TERM CONSEQUENCES}

I already have expressed doubt about whether the Supreme Court's institutional stature and legitimacy depend much, in the long term, on the quality of the legal reasoning in its opinions. ${ }^{132}$ Rather, the judgment of history seems to depend more on whether the Court generally reaches the

contending parties invoke the process of the courts, however, it becomes our unsought responsibility to resolve the federal and constitutional issues the judicial system has been forced to confront.").

128. On the other hand, in defense of the state supreme court, Florida precedents really do emphasize the importance of effectuating the will of the voters in election contests. See sources cited supra note 122.

129. Bush, 531 U.S. at $142-43$ (Ginsburg, J., dissenting) ("Were the other Members of this Court as mindful as they generally are of our system of dual sovereignty, they would affirm the judgment of the Florida Supreme Court.").

130. Wright v. West, 505 U.S. 277, 291 (1992) (Thomas, J., plurality opinion) (habeas proceeding); id. at 371 (Scalia, J., dissenting); see also O'Dell v. Netherland, 521 U.S. 151, 156 (1997) (Thomas, J.) (under Teague, federal courts on habeas review must defer to state courts' "reasonable, good-faith interpretations" of federal court precedent); Sandra D. O'Connor, Trends in the Relationship Between the Federal and State Courts from the Perspective of a State Court Judge, 22 WM. \& MARY L. REV. 801, $\$ 13$ (1981) ("There is no reason to assume that state court judges cannot and will not provide a 'hospitable forum' in litigating federal constitutional questions.").

131. Cf. Planned Parenthood v. Casey, 505 U.S. 833, 995-1002 (1992) (Scalia, J., dissenting) (analogizing Casey to Dred Scott, lambasting the notion that the Court can settle great national controversies through constitutional adjudication, and lauding the idea of local rather than national solutions).

132. See supra text accompanying notes 7-10. 
"right" results, by which I mean simply that its decisions prove consonant with long-term popular opinion. Of course, neasuring the Court's relative institutional stature at any particular point in time is difficult. Identifying with any degree of precision the factors that contribute to or detract from that stature is virtually impossible. Necessarily, then, much of what follows is impressionistic.

A quick canvass of American constitutional history identifies several factors that may influence the way in which particular Supreme Court decisions influence the public's estiniation of the Court. First, I shall try to identify the relevant variables. Then, I will illustrate their application with concrete examples from American constitutional history. Finally, I shall consider how these variables apply in the context of Bush v. Gore. My goal is to shed light on how that ruling is likely to impact the Court's long-term standing.

My basic premise, to repeat, is that the Court's institutional standing ultimately depends on producing decisions that garner the long-term approval of the American public. The principal variable influencing the Court's reputation is how popular or unpopular its decisions are. Second, in addition to the amount of support and opposition to particular decisions, the intensity of that sentiment-how strongly supporters and opponents feel about the underlying issue-influences the Court's standing. Third, and relatedly, intensity of opposition is a function not only of how strongly people feel about an issue, but also how convinced they are that the Court decision resolving that issue will be implemented, rather than evaded or even nullified. Court rulings that are adverse to a constituency's treasured interests, but that are unlikely to prove efficacious, probably will not generate tremendous resistance. Fourth, the relative power of the constituencies that support and oppose the Court's rulings nuay be relevant to its long-term legitiniacy. Decisions that alienate relatively powerful interest groups are more likely to affect adversely the Court's stature. Fifth, some constitutional issues linger, while others fade away. Controversial decisions on topics that quickly become obsolete are unlikely to do the Court much long-term harm. Sixth, public opinion changes, often quite dramatically, on some constitutional issues but not others. Court decisions that imitially prove controversial may be regarded later as great moral victories. Conversely, some rulings that initially were approved subsequently are deemed moral disasters. Seventh, Justices sonietimes, but not always, enjoy subsequent opportunities to adjust their original decision, thus modulating results that initially proved controversial. Eighth, contentious constitutional decisions sometimes come in packages. A ruling that might not have significantly inipaired the Court's standing had it been an isolated event, may weaken an institution already under siege because of contemporaneous decisions. 
lt may be helpful to flesh out these variables with some concrete illustrations from American constitutional history. It stands to reason that unpopular decisions will threaten the Court's long-term standing, especially given the tenuous legitimacy of ostensibly countermajoritarian judicial review in a democratic system. ${ }^{133}$ Historically, the Justices, perhaps comprehending this risk, generally have used the Constitution to suppress outlier state practices. Such decisions are, almost by definition, likely to generate support among national majorities. One may be surprised to discover how many of the Court's notable constitutional rulings fit this suppression-of-outliers description. By no means an exhaustive list includes Troxel v. Granville ${ }^{134}$ (parental rights); Romer v. Evans ${ }^{135}$ (gay rights); United States v. Virgini ${ }^{136}$ (sex discrimination in public universities); Plyler v. Doe ${ }^{137}$ (right of children of illegal aliens to free public education); Moore v. City of East Cleveland ${ }^{138}$ (familial relationships); Coker v. Georgia $^{139}$ (proportionality review in connection with the death penalty); Harper v. Virginia Board of Elections ${ }^{140}$ (poll tax); Griswold v. Connecticut $^{141}$ (right to use contraceptives); Brown v. Mississippi ${ }^{142}$ (coerced confessions); and Nixon v. Herndon ${ }^{143}$ (White primary). ${ }^{144}$ On all these occasions, judicial invalidation of state legislation was relatively uncontroversial because national majorities agreed with the results of the Court's constitutional interpretations. Small wonder that an institution that is able generally to mirror national opimion, while simultaneously perpetuating the noble myth that it heroically defends minority rights from majoritarian oppression, remains so popular with the American public..$^{145}$

Of course, some of the Court's most famous constitutional rulings do not fit this paradigm. On these other, more exceptional occasions, roughly half the country agrees with the Court's decision, while the other half disagrees. I believe this is a generally accurate description of Prigg $v$.

133. See, e.g., AleXander Bickel, The Least Dangerous Branch 16-23 (1962).

134. 530 U.S. $57(2000)$.

135. 517 U.S. $620(1996)$.

136. 518 U.S. 515 (1996).

137. 457 U.S. 202 (1982).

138. 431 U.S. 494 (1977).

139. 433 U.S. 584 (1977).

140. 383 U.S. 663 (1966).

141. 381 U.S. 479 (1965).

142. 297 U.S. $278(1936)$.

143. 273 U.S. 536 (1927).

144. 1 provide support for the claim that these decisions involved suppression of outlier state practices in Michael J. Klarman, Rethinking the History of American Freedom, 42 WM. \& MARY L. Rev. 265, 279 nn.60-65 (2000) (book review).

145. Statements subscribing to this myth are collected in Michael J. Klarman, Rethinking the Civil Rights and Civil Liberties Revolutions, 82 VA. L. REv. 1, 1-3 \& nn.1-14 (1996). For speculation on why the inyth continues to hold sway, see $i d$. at 18-31. 
Pennsylvania ${ }^{146}$ (fugitive slave renditions); Dred Scott v. Sandford ${ }^{147}$ (slavery in the territories); Brown v. Board of Education ${ }^{148}$ (school desegregation); Furman v. Georgia ${ }^{149}$ (death penalty); Roe v. Wade ${ }^{150}$ (abortion); and Regents of the University of California v. Bakke ${ }^{151}$ (affirmative action). While such decisions are certain to prove more controversial than the suppression-of-outliers variety, at least the Justices can count on the support of roughly $50 \%$ of the nation.

On only a relative handful of occasions has the Court interpreted the Constitution in ways opposed by a clear majority of the nation. This rather small category includes decisions invalidating school prayer ${ }^{152}$ and criminal bans on flag burning, ${ }^{153}$ as well as safeguarding the rights of criminal defendants, such as Miranda v. Arizona. ${ }^{154}$ Even on these exceptional occasions, though, it would be a mistake to suppose that overwhelming popular majorities opposed the Court. The Justices invalidated school prayer and Bible reading only after the relative demise of the nation's unofficial Protestant establishment. ${ }^{155}$ Likewise, the Warren Court's criminal procedure revolution was rendered possible only by shifting public attitudes toward race, poverty, and totalitarian law enforcement practices. ${ }^{156}$ Thus, while national majorities have opposed the Court decisions in this category, a solid $30 \%$ to $40 \%$ of the American public has sided with the Justices. ${ }^{157}$

The number of times that an overwhelming majority of Americans has opposed the Court's constitutional interpretations probably can be counted on one hand. Chisholm v. Georgia, ${ }^{158}$ holding that nonconsenting states may be sued in federal court under Article III, clearly is such an instance. Morehead v. New York ex rel. Tipaldo, ${ }^{159}$ invalidating New York's mimmum wage law in the midst of the Great Depression, may well be another.

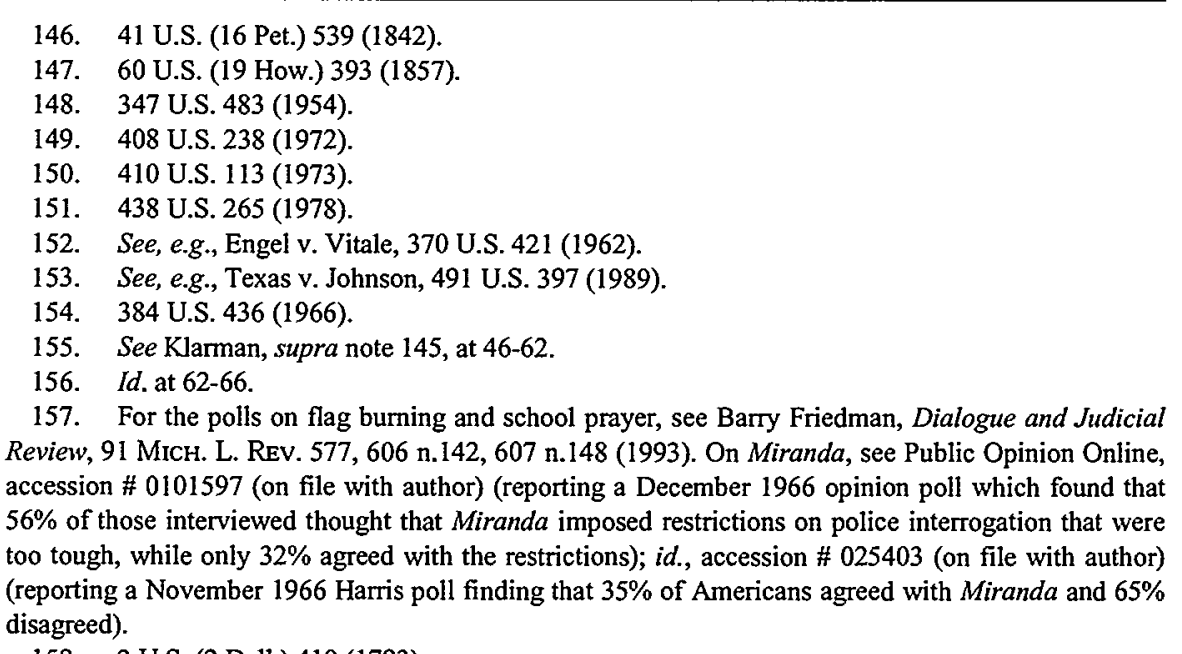

158. 2 U.S. (2 Dall.) 419 (1793).

159. 298 U.S. 587 (1936). 
Significantly, both of these decisions did harm the Court's standing. Chisholm was the Supreme Court's first significant constitutional decision, and the Justices got it so wrong (in the sense of contravening public opinion) that Congress immediately slapped them down, passing the Eleventh Amendment by majorities of nine-to-one $\mathrm{m}$ the House and eleven-to-one in the Senate. ${ }^{160}$ Chief Justice Jay concluded, as a result of this episode, that the Supreme Court never would achieve equal standing with the other branches of the national government; he resigned soon afterwards to become governor of New York. ${ }^{161}$ Similarly, Tipaldo was the straw that broke the camel's back during the New Deal constitutional crisis. ${ }^{162}$ While President Roosevelt and other Democrats had criticized earlier rulings striking down New Deal measures such as the National Industrial Recovery Act $^{163}$ and the Agricultural Adjustment Act, ${ }^{164}$ those statutes were sufficiently controversial that the Court decisions invalidating them commanded something close to majority support in the nation. ${ }^{165}$ By 1936 , however, both Democrats and Republicans endorsed state minimum wage legislation, and thus Tipaldo incited a firestorm of criticism. ${ }^{166}$ That ruling was the proximate cause of Roosevelt's Court-packing plan, a scheme that certainly would have damaged the Court's stature had it been enacted. Thus, constitutional rulings that contravene overwhelming public opinion, at least on salient issues, do jeopardize the Court's standing. No doubt cognizant of this reality, the Justices rarely have tempted fate by frustrating the wishes of dommant majorities.

Whether other rulings harmed the Court's reputation is partly a product of the intensity of preference mamifested by opponents of the Court's decisions. Thus, for example, Brown v. Board of Education generated furious resistance among southern Whites, opposition that succeeded at

160. William R. Casto, The Supreme Court in the Early Republic 200 (1995); 1 Charles Warren, The Supreme Court in Untred States History 101 (1926). On hostile public reaction to Chisholm, see id. at 96-101.

161. See Jay to Adams, Jan. 2, 1801, in 4 The Correspondence and Public Papers of John JAY 284, 285 (Henry P. Johnston ed., 1893) (noting that Jay had "left the bench perfectly convinced" that a judicial system "so defective" could never "obtain the energy, weight, and dignity which are essential to its affording due support to the national government, nor acquire the public confidence and respect which, as the last resort of the justice of the nation, it should possess").

162. See William Leuchtenburg, The Origins of FDR's Court-Packing Plan, 1966 SuP. Cr. REv. 347, 376-77.

163. A.L.A. Schechter Poultry Corp. v. United States, 295 U.S. 495 (1935).

164. Carter v. Carter Coal Co., 298 U.S. 238 (1936).

165. Barry Cushman, RethinkIng the New DEAL Court 34-35 (1998); Leuchtenburg, supra note 162 , at 368 .

166. See, e.g., William E. Leuchtenburg, The Supreme Court Reborn 105-06 (1995) (calling Tipaldo "the last straw" and noting that even the Republican Party had committed to overturning that decision by constitutional amendment). 
blocking implementation of the Court's edict for an entire decade. ${ }^{167}$ The Court's standing among southern Whites was severely impaired as a result of Brown and other Warren Court rulings. ${ }^{168}$ (The Court's standing recovered as national, including southern, opinion changed dramatically on the race issue as a result of the 1960s' civil rights movement. ${ }^{169}$ ) Similarly, Dred Scott $v$. Sandford, which undercut the very legitimacy of the Republican Party, predictably produced ferocious opposition among the party faithful. ${ }^{170}$ During the Civil War and Reconstruction, as many more Americans rallied to the Republican banner and concluded that Dred Scott had been an egregious mistake, the Court's standing probably did suffer, at least for a short period of time. ${ }^{171}$

Conversely, while a majority of Americans opposed the Court's flagburning decisions of $1989-90,{ }^{172}$ that opposition does not appear to have been intensely committed, judging by the relative rapidity with which the

167. See Bartley, supra note 82; NeIl R. McMillen, The Citizens' Council: Organized Resistance to the Second Reconstruction, 1954-64 (1971); Benjamin Muse, Ten Years of Prelude: The Story of Integration Since the Supreme Court's 1954 Decision (1964).

168. See, e.g., C. Herman Pritchett, Congress Versus the Supreme Court 1957-1960, at 18 (1961) (noting attacks on the Court by southerners that "were vituperative in the extreme, calling into question not only the ability but also the motives and the patriotism of the justices"); WALTER F. Murphy, Congress and the Court: A Case Study in the American Political Process 264-65 (1962) (noting polls revealing a rise in the Supreme Court's unfavorable ratings among White southerners after Brown). BRADY, supra note 7, conveys a vivid sense of how Whites in the deep South felt about the Supreme Court as a result of Brown.

169. See, e.g., Poll Finds Gains for Integration, N.Y. Times, May 3, 1970, at 53 (reporting a Gallup Poll released in May 1970 which revealed that only $16 \%$ of southern Whites opposed sending their children to school with any Blacks, as compared with $61 \%$ in 1963); Public Opinion Online, accession \# 0065113 (on file with author) (reporting a September 1970 Harris poll showing that $55 \%$ of Americans agreed with recent Supreme Court decisions calling for immediate desegregation and $32 \%$ disagreed).

170. See, e.g., Don E. Fehrenbacher, The Dred Scott Case: Its Significance in American Law and History 423-27 (1978); 2 Chardes Warren, The Supreme Court In United States History 302-09 (I926); The Dred Scotr Decision: LaW or Politics? 46-50, 56-63 (Stanley I. Kutler ed., 1967) (reproducing Republican editorial and political criticism).

171. See, e.g., WALKer LewIs, WIthout FEAR OR Favor 423 (I965) (noting that Dred Scott "impaired the prestige of the Court for ycars to come"); id. at 470-71 (noting ferocious Republican attacks on Chief Justice Taney after his death in 1864); Charles Evans Hughes, The Supreme Court of the United States, Its Foundation, Methods and Achievements 51 (1928) ("It was many years before the Court, even under new judges, was able to retrieve its reputation."); Edwin Corwin, The Dred Scott Decision, in Light of Contemporary Legal Doctrines, 17 AM. Hist. Rev. 52, 68-69 (1911) (concluding that the process of "recuperating its sbattered reputation" was "so slow and laborious" that the Court did not "play anything like its due role of supervision" during the Civil War and Reconstruction). But see FEHRENBACHER, supra note 170, at 579 ("[T] he notion that the Supreme Court, owing to its association with the Dred Scott decision, was in mortal danger during the Civil War, is largely fiction."); Stanley I. Kutler, Judicial Power and Reconstruction Politics 7-11 (1968) (distinguishing between criticism of Dred Scott and criticism of the Court as an institution, and denying that Dred Scott significantly impaired the Court's national standing).

172. See Friedman, supra note 157, at 606 n.I42. 
flag-burning issue has died away. ${ }^{173}$ Similarly, one reason that the Court's school prayer decisions have not significantly impaired its stature, notwithstanding opposition from sixty to seventy percent of the American public, may be that critics are not intensely committed to the sort of watereddown, nondenominational prayer that was at issue in Engel $v$. Vitale and that likely would be reinstated were that decision ever to be overturned. ${ }^{174}$

Intensity of opposition is partly a product of how efficacious the Court's rulings are deemed likely to be. When the Supreme Court invalidated residential segregation ordinances in Buchanan v. Warley ${ }^{175}$ in 1917, the White South received the news calmly, secure in the knowledge that residential segregation could be maintained without formal legal sanction. ${ }^{176}$ Similarly, when the Court in Norris v. Alabama ${ }^{177}$ in 1935 overturned the second round of convictions of the Scottsboro Boys on the ground that Blacks had been systematically excluded from the juries that indicted and convicted them, southern White reaction was muted, not because opposition to Black jury service had significantly eroded, but rather because of confidence that the ruling easily could be circumvented. ${ }^{178}$ Likewise, one reason that the Warren Court's criminal procedure revolution has not significantly impaired the Court's standing may be that legislatures have successfully blunted its impact by refusing to adequately fund counsel for indigent defendants, thus disabling defendants from taking full advantage of the panoply of constitutional rights identified by the Court. ${ }^{179}$

Conversely, one reason Brown aroused a firestorm of resistance among White southerners is that, by 1954 , they doubted their ability to control the decision's impact, given the increased assertiveness of southern Blacks inspired by World War $\mathrm{I}$, the diminished availability of violence as a method of ensuring racial subordination, and the heightened attentiveness of the federal executive to civil rights issues. ${ }^{180}$ Similarly, opposition to Roe v. Wade has been intense partly because the decision has proven

173. See Robert Justin Goldstein, Flag Burning AND Free SPeEch 226 (2000) (noting that after the Supreme Court's flag-burning decisions of 1989 and 1990, the issue disappeared "with a stunning quickness and completeness").

174. For the actual prayer at issue in that case, see Engel, 370 U.S. at 422.

175. 245 U.S. 60 (1917).

176. Richmond News Leader, Nov. 6, 1917, at 4-5; Wesley G. Marshall, The Dawn is Breaking: Buchanan v. Warley and the Fight Against Residential Segregation 99 (1985) (unpublished M.A. thesis, University of Virginia) (on file with author).

177. 294 U.S. 587 (1935).

178. See sources cited in Michael J. Klarman, The Racial Origins of Modern Criminal Procedure, 90 Mich. L. Rev. $48,80 \mathrm{nn} .155-56$ (2000).

179. See William Stuntz, The Uneasy Relationship Between Criminal Procedure and Criminal Justice, 107 YALE L.J. 1 (1997).

180. See generally Michael J. Klarman, Netrher Hero, nor Vitlain: The Supreme Court, RACE, and the Constitution IN the Twentietr Century ch. 4 (analyzing the Supreme Court's approach to race issues during the World War II era) (forthcoming 2003). 
difficult to nullify, given the market incentives it created for abortion suppliers. ${ }^{181}$

Another factor influencing whether controversial constitutional decisions adversely affect the Court's standing is the relative power wielded by supporters and critics. Not all constituencies affected by Court decisions exercise the same clout. For example, Court rulings from the late nineteenth and early twentieth centuries invalidating the progressive income tax and striking down minimum wage, maximum hour, and protective union legislation were intensely controversial. ${ }^{182}$ Yet opponents of these decisions, on average, lacked the economic and political resources of supporters. Similarly, more recent controversial decisions such as Roe v. Wade and Engel $v$. Vitale generally have won the endorsement of the nation's cultural elite, which tends to be both better educated and more socioeconomically advantaged than the average American. ${ }^{183}$ While nearly half the country has criticized the abortion decision and more than half has opposed the school prayer ruling, the Court's defenders exercise relatively greater economic, political, and cultural clout, thus reducing the likelihood that these rulings will diminish the Court's stature. Even more dramatically, opponents of Plessy v. Ferguson, ${ }^{184}$ the Court's first decision rejecting an equality-based challenge to racial segregation, exercised almost no power at all. Whites overwhelmingly endorsed Plessy, and African Americans at the turu of the last century were politically disfranchised and economically marginal. ${ }^{185}$ Conversely, an important component of the opposition to Reynolds v. Sims,${ }^{186}$ the reapportionment decision, consisted of politicians, who wield enormous political power (overrepresented rural dwellers also opposed Reynolds, though such groups were, in most cases, a minority of a minority of the population). These politically influential critics of Reynolds nearly were able to secure a constitutional amendment overturning the decision. ${ }^{187}$ Yet, once that effort had failed, Reynolds quickly generated its own powerful constituency of supporters: politicians elected under the

181. See Gerald N. Rosenberg, The Hollow hope: Can Courts Bring About Soctal Change? 195-201 (1991).

182. The leading cases included Adkins v. Children's Hosp., 261 U.S. 525 (1923) (minimum wage law); Coppage v. Kansas, 236 U.S. 1 (1915) (pro-union legislation); Lochner v. New York, 198 U.S. 45 (1905) (maximum hour law); Pollock v. Farmers Loan \& Trust Co., 158 U.S. 601 (1895) (income tax). For the controversy generated by such decisions, see generally WiLliam Ross, A MUTED Fury: Populists, Progressives, And Labor Unions Confront the Courts, 1890-1937 (1994).

183. On this culturally elite bias of judicial review, see Michael J. Klarman, What's So Great About Constitutionalism?, 93 Nw. U. L. REv. 145, 188-92 (1998).

184. 163 U.S. 537 (1896).

185. See Michael J. Klarman, The Plessy Era, 1998 SuP. CT. Rev. 303.

186. 377 U.S. 533 (1964).

187. See David Kyvig, Explicit AND Authentic Acts 374-76 (1996). 
one-person-one-vote regime of Reynolds had a vested interest in defending that decision. ${ }^{188}$

Some constitutional issues fade away and others linger. The Court's prestige is not jeopardized by controversial or even unpopular rulings on issues that quickly lose their salience. For example, the public controversy over Dred Scott, which was intense in the late $1850 \mathrm{~s},{ }^{189}$ dissipated rapidly once the Civil War and postwar constitutional amendinents had abolished slavery and guaranteed Black citizenship, thus rendering Dred Scott obsolete. The Court's rulings invalidating New Deal legislation in 1935 and $1936^{190}$ suffered a similar fate. The immediate effect of these decisions was to produce a confrontation with the president that threatened the Court's standing; Roosevelt's Court-packing plan had the potential to destroy the Court as we know it. ${ }^{191}$ Yet once the Justices shifted constitutional gears, ${ }^{192}$ economic legislation quickly became immune from constitutional challenge. ${ }^{193}$ The issue that had provoked the Court-packing episode was obsolete within just a couple of years. ${ }^{194}$ Likewise, the decision in Korematsu $v$. United States, ${ }^{195}$ sustaining the wartime internment of Japanese Americans, already was generating considerable criticism by the end of the war, ${ }^{196}$ and soon would come to be regarded as a quintessential failure of judicial nerve. ${ }^{197}$ Yet, since the underlying issue simply was not relevant to peacetime America, the decision did little lasting damage to the Court's reputation. Other issues that generate Court decisions refuse to go away.

188. See John Hart Ely, Democracy and Distrust 121 (1980) ("[T]he incentive of elected representatives is not necessarily toward malapportionment but rather toward maintaining whatever apportionment, good or bad, it is that got and keeps them where they are.").

189. See supra note 170.

190. See supra notes 163-164.

191. CuSHMAN, supra note 165, at 13-14 (reporting statements by opponents of the plan); JOSEPH Alsop \& Turner Catledge, The 168 Days 107, 114-15 (1938) (same).

192. Constitutional historians continue to debate precisely when and why that shift occurred. Compare Cushman, supra note 165 (denying that any fundamental shift occurred in 1937), with Bruce Ackerman, We the People: Transformations 366-68 (1998) (arguing there was a revolution in 1937), and LeUchTENBURG, supra note 166, at ch. 8 (same). See also Richard D. Friedman, Switching Time and Other Thought Experiments: The Hughes Court and Constitutional Transformation, 142 U. PA. L. Rev. 1891, 1982 (1994) (denying any "revolution" but conceding greater significance to Jones \& Laughlin Steel than does Cushman).

193. See, e.g., Williamson v. Lee Optical, 348 U.S. 483 (1955); Railway Express Agency v. New York, 336 U.S. 106 (1949).

194. See generally Walton H. Hamilton \& George D. Braden, The Special Competence of the Supreme Court, 50 YaLE L.J. 1319, 1340-41 \& n.82 (1941) (collecting cases).

195. 323 U.S. 214 (1944).

196. See, e.g., Eugene V. Rostow, The Japanese American Cases-A Disaster, 54 YALE L.J. 489 (1945); Nanette Dembitz, Racial Discrimination and the Military Judgment: The Supreme Court's Korematsu and Endo Decisions, 45 Colum. L. REv. 175 (1945).

197. See, e.g., Judith A. Baer, Equaltty Under the Constitution: Reclaiming the FourTeENTH AMENDMENT 113, 149 (1983) (calling Korematsu "racist" and a "disgrace"); MichaEL PerRy, The Constitution IN THE Courts: LAW OR Polmtics? 145 (1994) (calling the decision "almost universally discredited"); Laurence H. Tribe, In What Vision of the Constitution Must the Law be Color-Blind?, 20 J. Marshall L. Rev. 201, 202 (1986) (calling Korematsu "infamous"). 
Abortion and school prayer have remained at the center of public controversy for well over a quarter of a century since the Court first put them on its constitutional agenda. ${ }^{198}$ Whether or not Roe and Engel have damaged the Court's standing, it seems clear that controversial rulings on issues that have staying power pose a relatively greater threat to the Court's reputation.

Just as the diminishing salience of an issue may affect the Court's ability to weather a storm of public controversy, significant shifts in public opinion on issues that retain their salience may impact the Court's standing as well. Brown v. Board of Education was intensely controversial in 1954, but was much less so by 1964, and by 1974 enjoyed the strong support of Americans, Black and White, North and South. ${ }^{199}$ Roe v. Wade, on the other hand, is nearly as controversial today as it was in $1973 .{ }^{200}$ Thus, the Court's reputation may depend, to a significant degree, on the Justices' skill at predicting the future. Brown is the greatest judicial prognostication of all time. The Justices rightly understood that a fundamental shift in race relations was in the offing. ${ }^{201}$ By acting as part of the vanguard of the civil rights movement, the Justices garnered substantial-indeed, somewhat exaggerated-credit for the transformation in race relations that ensued. ${ }^{202}$

Yet, public opinion does not always shift with the Court; it can move in the opposite direction as well. Thus, a Court decision that is initially popular or that generates a mixed response can later become so universally criticized as to subject the Court to popular vilification. Dred Scott and Plessy surely illustrate this phenomenon, and Korematsu may as well. ${ }^{203}$

198. See, e.g., Stenberg v. Carhart, 530 U.S. 914 (2000) (invalidating restrictions on "partial birth" abortion); Santa Fe Independent School Dist. v. Doe, 530 U.S. 290 (2000) (invalidating praycr at high school football games).

199. See supra note 169; see also MuSE, supra note 167, at 211 (noting a dramatic increase by the carly $1960 \mathrm{~s}$ in the percentage of southerners who believed school desegregation was inevitable); $i d$. at 270-71 (noting a dramatic shift in national opinion on raee by 1963).

200. Compare Public Opinion Online, accession \# 0380244 (on file with author) (reporting a Roper opinion poll from April 2001 revealing that $47 \%$ of Americans consider themselvcs pro-choice, as opposed to $41 \%$ who consider themselves pro-life) with id., accession \# 0045804 (reporting a March 1974 Gallup opinion poll showing that $47 \%$ of Americans supported Roe $v$. Wade and $44 \%$ opposed it).

201. For the Justices' perception that racial change was in the offing, see the statements quoted in Michael J. Klarman, Civil Rights Law: Who Made It and How Much Did It Matter?, 83 Geo. L.J. 433, 458 (1994) (book review). For the extralegal causes of this changc, see Michael J. Klarman, Brown, Racial Change, and the Civil Rights Movement, 80 VA. L. Rev. 7, 13-75 (1994).

202. For the debate over how much credit the Court deserves, compare Gerald N. Rosenberg, Brown Is Dead! Long Live Brown!: The Endless Attempt to Canonize a Case, 80 VA. L. REv. 161 (1994) (almost no credit) with David J. Garrow, Hopelessly Hollow History: Revisionist Devaluing of Brown v. Board of Education, 80 VA. L. REV. 151 (1994) (trcmendous credit), and Michael J. Klarman, Brown v. Board of Education: Facts and Political Correctness, 80 VA. L. REv. 185 (1994) (indireet and moderate credit).

203. Dred Scott probably enjoyed majority support in the nation when decided. FEHRENBACHER, supra note 170, at 565-66 (noting that Dred Scott seemed, if anything, to help northern Democrats in the 1857 state elections). Plessy was so consonant with public opinion that it went virtually unnoticed. See, e.g., Charles A. Lofgren, The Plessy Case: A Legal-Historical Interpretation 197 
Fortunately for the Court, dramatic shifts in public opinion that render the Court a target of public vituperation frequently occur on issues that the passage of time has rendered largely obsolete. On such occasions, even nearly universal pubhic condemnation of its rulings seems to take little toll on the Court's standing. Within a decade or two of the decisions, few Americans were prepared to defend Dred Scott or, to a lesser extent, Korematsu. ${ }^{204}$ Yet, since the issues adjudicated in these cases had been rendered largely obsolete, the rulings became curiosities rather than irritants. If this observation is correct, there may be a one-way ratchet of sorts at work with regard to controversial Court decisions on issues where a dramatic shift in public opinion subsequently occurs. Apparently, the Justices receive enormous credit for correctly predicting the future, but not much blame for incorrectly predicting it, at least when the underlying issue quickly loses its salience. Concretely, the Court's heroic decision in Brown seems, in the public mind, vastly to outweigh ignoble judicial deeds such as Dred Scott, Plessy, Korematsu, and the like. ${ }^{205}$

On other issues, public opinion changes, while the salience of the issue reinains high. In this category of cases, significantly, the Justices generally enjoy second chances to get their decisions right-that is, they have opportunities to reconsider their initial ruling and, if necessary, to revise or retract it, in light of hostile public opinion. Furman $v$. Georgia may be the best exemplar of this phenomenon. In 1972, Supreine Court Justices read the tea leaves of public opinion as indicating that capital punishment in the Uinted States was on the road to extinction. ${ }^{206}$ Opinion polls in the mid1960s revealed, for the first and thus far only time in American history,

(1987); Benno C. Schmidt, Jr., Principle and Prejudice: The Supreme Court and Race in the Progressive Era, 82 Colum. L. REv, 444, 469 (1982). Korematsu was exactly what most Americans demanded during the war. PETER IRONS, Justice AT WAR ch. 3 (1983). For subsequent vilification of these decisions, see the statements quoted in Klarman, Civil Rights, supra note 145, at 25, 28.

204. On Korematsu, see, for example, The Autobiography of Wirliam O. Douglas: The CourT Years, 1939-1975, at 280 (1980) (recanting his vote in Korematsu); Irons, supra note 203, at 362 (noting a 1983 report to Congress by the Commission on Wartine Relocation, which concluded that the internment of Japanese Americans was a "grave injustice" resulting from "race prejudice"). On Dred Scott, see FEHRENBACHER, supra note 170, at 573 ("as time passed, [Dred Scott] was an embarrassment-the Court's highly visible skeleton in a transparent closet"); Downes v. Bidwell, 182 U.S. 244, 273-74 (1901) (noting that the Civil War had "produced such changes in judicial, as well as public sentiment, as to seriously impair the authority of [Dred Scott]").

205. Apparently, the myth of the Court as countermajoritarian hero is just too attractive to resist. See Klarman, Civil Rights, supra note 145, at 19-23.

206. Delavan Dickson, The Supreme Court in Conference: 1940-1985, at 617 (2001) (conference notes from Furman v. Georgia: Justice Brennan noting that support for abolition of the death penalty has imcreased during the twentieth century; Justice Stewart predicting that "[s]omeday the Court will hold that the death sentence is unconstitutional"); see also Furman v. Georgia, 408 U.S. 238, 313 (1972) (White, J., concurring) (observing that the death penalty "has for all practical purposes run its course"); Jeffries, supra note 10, at 413-14. 
national pluralities opposed to capital punishment. ${ }^{207} \mathrm{~A}$ majority of the Justices decided to give the death penalty a nudge toward constitutional oblivion. ${ }^{208}$ Yet, public opinion on the death penalty shifted dramatically in the mid-1970s, perhaps partly in reaction to the Court's ruling. ${ }^{209}$ Within four years of Furman, thirty-five state legislatures had manifested their desire to retain the death penalty, by revising their statutes to take account of the objections raised in Furman. ${ }^{210}$ The Justices, plainly influenced by this resounding popular endorsement of the death penalty, ${ }^{211}$ switched gears in 1976, sustaiming the constitutionality of the death penalty, provided it is administered in a suitably constrained manner. ${ }^{212}$ We know from subsequent experience in California that determined judicial resistance to implementation of the death penalty in the face of overwhelming popular approval can injure a court's stature. ${ }^{213}$ The United States Supreme Court avoided incurring the public's wrath because it took advantage of postFurman opportunities to align its death penalty jurisprudence with national opinion.

The so-called "switch in time" of 1937 likewise illustrates how the iterative quality of constitutional interpretation affords the Court opportunities to conserve its institutional prestige by adjusting, or even retracting, initially controversial decisions. President Roosevelt threatened to destroy the Court in response to its 1936 decisions invalidating the Bituminous Coal Conservation Act, the Agricultural Adjustment Act, and the New York minimum wage law. ${ }^{214}$ The very next year, the Justices took advantage of opportunities to reconsider their position, and by doing so, helped

207. Jeffries, supra note 10 , at 406; Carole S. Steiker \& Jordan M. Steiker, Sober Second Thoughts: Reflections on Two Decades of Constitutional Regulation of Capital Punishment, 109 HaRv. L. REv. 355, $410 \mathrm{n} .273$ (1995) (noting that in 1966 a Gallup poll, for the first time ever, revealed more Americans opposing than favoring the death penalty).

208. Jeffries, supra note 10 , at 413 .

209. Jeffries, supra note 10 , at 414 (reporting Gallup polls and concluding that the increase in public support for the death penalty after Furman was "so sharp that it seems almost certain to have been a negative reaction to the Court's decision"); Steiker \& Steiker, supra note 207, at 411-12 ("[1]t seems fair to say that Furman galvanized political opposition to abolition . ...").

210. Gregg v. Georgia, 428 U.S. 153, 179-80 (1976) (plurality opinion); Jeffries, supra note 10, at 414; Steiker \& Steiker, supra note 207 , at 40.

211. Dickson, supra note 206, at 620-21 (citing conference notes in Gregg v. Georgia: Justice Stewart noting that thirty-five legislatures have revised their death penalty statutes since 1972 , thus indicating that "evolving standards of decency" continue to support the death penalty; Justice Powell emphasizing the recent state statutes).

212. See, e.g., Gregg v. Georgia, 428 U.S. 153 (1976).

213. See, e.g., Robert S. Thompson, Judicial Independence, Judicial Accountability, Judicial Elections, and the California Supreme Court: Defining the Terms of the Debate, 59 S. CAL. L. REv. 809, 812, 847-50, 858-59 (1986) (describing successful recall efforts against California Supreme Court Justices who were perceived to have frustrated the voters' will regarding the death penalty).

214. Carter v. Carter Coal Co., 298 U.S. 238 (1936); United States v. Butler, 297 U.S. 1 (1936); Morehead v. New York ex rel. Tipaldo, 298 U.S. 587 (1936). 
ensure the defeat of Roosevelt's Court-packing plan. ${ }^{215}$ Many commentators have interpreted Terry $v$. Ohio, ${ }^{216}$ which sustained police stop-and-frisk tactics even in the absence of probable cause, as a judicial (and judicious) concession to public opinion, which had been agitated by the Court's decision in Miranda $v$. Arizona two years earlier. ${ }^{217}$ The apparent shift in the Court's attitude toward time-release programs for religious observance in public schools between 1948 and 1952, ${ }^{218}$ and toward legislative investigation of alleged communists between 1957 and 1959, ${ }^{219}$ likewise may reflect the Justices' recognition of the wisdom of making occasional concessions to adverse public opinion.

Finally, the Court's standing and legitimacy are most at risk when it renders unpopular or controversial decisions in bunches, rather than individually. The Court came under severe attack in the late 1950s-from Congress, the American Bar Association, the Conference of State Chief Justices, and legal academics-because it took on so many controversial causes simultaneously. ${ }^{220}$ Still reeling from the White South's assault upon Brown, the Justices tempted fate by taking on the professional anti-Communists with their famous Red Monday decisions of $1957,{ }^{221}$ the law enforcement lobby with some forerunners of the $1960 \mathrm{~s}$ criminal

215. The relevant decisions are West Coast Hotel Co. v. Parrish, 300 U.S. 379 (1937); NLRB v. Jones \& Laughlin Steel Corp., 301 U.S. 1 (1937); and Steward Machine Co. v. Davis, 301 U.S. 548 (1937). For the impact of these decisions on the Court-packing plan, see CUSHMAN, supra note 165, at 1S-23; ALsop \& CATLEDGE, supra note 191, at 144-47. Cushman, of course, denies that these decisions represented, in any strong sense, "reconsideration" of the decisions from the preceding term.

216. 392 U.S. 1 (1978).

217. See, e.g., Tracy Maclin, Terry v. Ohio's Fourth Amendment Legacy: Black Men and Police Discretion, 72 ST. JoHN's L. REV. 1271, 1317 (1998) (attributing Terry to a prevalent public perception that the Court in decisions such as Miranda "had gone too far in policing the police").

218. Compare McCollum v. Board of Education, 333 U.S. 203 (1948) (invalidating time-release program) with Zorach v. Clauson, 343 U.S. 306 (1952) (sustaining a slightly different time-release program). See also C. Herman Prtrchetr, Civil Liberties and the Vinson Court 14 (1954) (attributing the shift to the Court's "dispos[ition] to use any available method to quiet the storm caused by the McCollum decision"); Melvin I. URofsky, Division and Discord: THE Supreme Court UNDER STONE AND VINSON, 1941-1953, at 236 (1997) (noting that McCollum "stirred up a nationwide furor among religious groups" and that many have attributed the result in Zorach to the strong public outcry against the earlier decision).

219. Compare Sweezy v. New Hampshire, 354 U.S. 234 (1957) (placing constitutional limits on legislative investigations), and Watkins v. United States, 354 U.S. 178 (1957) (same), with Uphaus v. Wyman, 360 U.S. 72 (1959) (narrowly construing those limits), and Barenblatt v. United States, 360 U.S. 109 (1959) (same). Murphy identifies a "tactical withdrawal" by the Court in 1959. MURPHY, supra note 168, at 246. Pritchett concludes that Barenblatt and Uphaus "suggest that the attacks [on the Court] did in fact take some toll of the Court's will to resist." PrrTcheTT, supra note 168, at 132.

220. MURPHY, supra note 168 , at 266 (arguing that the Warren Court made the mistake of taking on "too many powerful enemies at one time"); PrTcherT, supra note 168, at 15-20 (noting that, in addition to the national security issue, the Court's rulings on school desegregation, criminal procedure, and various federalism issues had alienated powerful constituencies).

221. Watkins v. United States, 354 U.S. 178 (1957); Sweezy v. New Hamphsire, 354 U.S. 234 (1954); Yates v. United States, 354 U.S. 298 (1957). These are discussed in MuRPHY, supra note 168, at 100-06; PrITCHETT, supra note 168, chs. 4-5. 
procedure revolution, ${ }^{222}$ and federalism aficionados with the beginnings of the habeas revolution. ${ }^{223}$ The Court simply offended too many powerful constituencies at once, and was forced to backtrack in the late 1950s, rejecting the broadest implications of its Red Monday decisions in 1959, 224 and generally absenting itself from the school desegregation controversy until after the civil rights movement had caught the country up with the Court. $^{225}$ Likewise, the New Deal Court got itself into trouble by invalidating numerous federal statutes in just eighteen months. ${ }^{226}$ Finally, a series of Marshall Court decisions between 1816 and $1824^{227}$ made the Court so unpopular in so many states that a genuine risk of congressional retaliation arose, either in the form of a statute curtailing the Court's appellate jurisdiction, or a constitutional amendment fundamentally altering the judicial review power. ${ }^{228}$ Most scholars believe that the Marshall Court engaged in a strategic retreat during its final decade, in order to blunt these retaliatory efforts. ${ }^{229}$

These seem to me the most important factors influencing how particular decisions impact the Court's long-term standing. Evaluating the

222. See, e.g., Mallory v. United States, 354 U.S. 449 (1957) (invalidity of confession made when defendant was not promptly brought before a magistrate, as required by Federal Rules of Criminal Procedure); Jencks v. United States, 353 U.S. 657 (1957) (defendants' right of access to relevant information contained in prosecutor's files).

223. Brown v. Allen, 344 U.S. 443 (1953) (dramatically expanding the scope of relief available under federal habeas corpus review).

224. Uphaus v. Wyman, 360 U.S. 72 (1959); Barenblatt v. United States, 360 U.S. 109 (1959).

These are discussed in MURPHY, supra note 168, at 229-31; PRTrCHETT, supra note 168, at 48-58.

225. On the Court's absenting itself from the school desegregation controversy, see, for example, J. Harvie Wilkinson, From Brown to Bakke: The Supreme Court and School Integration 1954-1978, ch. 5 (1979). The Court did intervene, but only in extreme circumstances. Cooper v. Aaron, 358 U.S. 1 (1958) (defiance of Brown, followed by school closures); Bush v. Orleans Parish Sch. Bd., 365 U.S. 569 (1961) (summarily affirming invalidation of state statute authorizing closure of any school ordered to integrate). The Court only reentered the fray as the civil rights movement reached its pinnacle. See Goss v. Bd. of Educ., 373 U.S. 683 (1963) (invalidating minority-to-majority student transfer policy); Griffin v. County Sch. Bd., 377 U.S. 218 (1964) (invalidating school closures).

226. See, e.g., Paul L. Murphy, The Constitution in Crisis Times, 1918-1969, ch.5 (1972) (describing the rulings and the crisis they generated).

227. See, e.g., Osbom v. Bank of United States, 22 U.S. (9 Wheat.) 738 (1824); Green v. Biddle, 21 U.S. (9 Wheat.) 1 (1823); Cohens v. Virginia, 19 U.S. (9 Wheat.) 264 (1821); Sturges v. Crowninshield, 17 U.S. (9 Wheat.) 122 (1819); Martin v. Hunter's Lessee, 14 U.S. (9 Wheat.) 304 (1816).

228. See, e.g., I WarRen, supra note 160, ch. 17; DWIGHT Wiley Jessup, Reaction and Accommodation: The United States Supreme Court and Polmical Conflict 1809-1835, ch. 5 (1987).

229. See, e.g., Jessup, supra note 228, chs. 6-7; R. Kent NeWmyer, The Supreme Court Under Marshall and Taney 84-88 (1968); G. Edward White, The Marshall Court and Cultural Change Vols. III-IV: History of the Supreme Court of the United States 950 (1988); Mark A. Graber, Federalist or Friends of Adams: The Marshall Court and Party Politics, 12 Studies AM. Pol. Devel. 229, 233 (1998). The leading cases in support of the retreat hypothesis are Hawkins v. Barney's Lessee, 30 U.S. (5 Pet.) 457 (1831); Providence Bank v. Billings, 29 U.S. (4 Pet.) 514 (1830); Willson v. Black Bird Creek Marsh Co., 27 U.S. (2 Pet.) 245 (1829); Ogden v. Saunders, 25 U.S. (12 Wheat.) 213 (1827). 
likely significance of Bush v. Gore according to these variables is straightforward, though necessarily no less impressionistic than identifying the relevant factors in the first place.

Half the country, the half that voted for Al Gore, thinks the result in Bush v. Gore was wrong; many think it was egregiously so. ${ }^{230}$ Some Republicans acknowledge (especially in private) that the Court's decision was bad law, but generally they are not unhappy with the result. ${ }^{231}$ Thus, if I am right that the Court's long-term legitimacy depends more on whether people approve its results than on the quality of its legal reasoning, roughly half the country will approve and roughly half will condemn $B u s h .{ }^{232}$ Yet, while nearly all Democrats criticize Bush, it is not clear how intense their opposition is. Surely most Americans are more energized by presidential elections than by flag burning. On the other hand, relatively few Gore supporters seem to have manifested an intensity of commitment for their candidate approaching that displayed by right-to-lifers in opposition to Roe $v$. Wade. Indeed, a principal reason that Gore found himself in the Florida predicament that he did (recall that all the political scientists' models predicted a relatively comfortable victory for him ${ }^{233}$ was the relative lack of enthusiasm evinced by many Democrats for their party's candidate. ${ }^{234}$ Thus one might surmise that many Democrats' opposition to Bush v. Gore will be lukewarn at best. My hunch, however, is that this supposition is mistaken. The commitment of many Democrats to contesting the Florida election results was less a product of their enthusiasm for their candidate than a reaction against what they regarded as the egregious misbehavior of Republicans during the election controversy. ${ }^{235}$ Once the Supreme Court

230. Richard Morin \& Claudia Deane, Public Backs Uniform U.S. Voting Rules, WASH. Post, Dec. 18, 2000, at Al (reporting an opinion poll revealing that $50 \%$ of the public approved of the Supreme Court decision and 48\% disapproved); Montgomery, supra note 34, at A10.

231. See sources cited supra note 23.

232. See Kaiser, supra note 15 , at A25 (quoting legal historian Lawrence Friedman to the effect that "[t]he country is split 50-50 politically, and they're probably split 50-50 on [Bush v. Gore]"); id. (quoting legal historian Howard Gillman to the effect that "[w] hat the court did was align itself with half the country against the other half').

233. Robert G. Kaiser, Academics Say It's Elementary, WASH. Post, Aug. 31, 2000, at A12 (noting that six of seven political scientists predicted Gore to win between $52.4 \%$ and $55.4 \%$ of the vote cast for the two major parties' candidates, and the seventh predicted him to win $60.3 \%$ ). I guess the political scientists have some remodeling to do before the next election.

234. See, e.g., Terry M. Neal, Some Black Voters View Gore as the Lesser of Two Evils, Wash. Post, Oct. 29, 2000, at A4 (noting doubts as to "whether Gore has generated the enthusiasm he needs among the Democrats' most loyal constituency [African-Americans]").

235. See, e.g., Naftali Bendavid \& Michael Tackett, Democratic Leaders Certify Their Support for Gore, $C_{\mathrm{H}}$. TRIB., Nov. 28, 2000, at 1 (noting Democratic anger over the tactics of Republicans in Florida and quoting one Democratic congressman observing that "[t]he actions of some of our more Republican partisans over the past few days have stiffened and strengthened the resolve of the Democrats"); Nicholas Confessore, Florida's Silver Lining: For Gore and the Democrats, Losing Ugly Beats Losing Nicely, THE AMER. Prospect OnLINE, Dec. 11, 2000, reprinted in BUSH v. GoRE, supra note 20, at 269, 270 (noting that the Bush camp's behavior was "so extreme, so over-the-top, that it had the unintended consequence of shoring up Gore's support among his own party"); Thomas B. Edsall, 
defied the pundits' predictions by involving itself in the election controversy, ${ }^{236}$ Democratic resentment toward Republican politicians and Bush campaign operatives easily was transferred to a conservative Supreme Court majority, seemingly bent on doing the GOP's bidding. My guess is that even lukewarm Gore supporters were outraged by the result in Bush v. Gore. Moreover, Bush proved to be one of the most efficacious decisions in the Court's history. The conservative majority ruled that the Florida manual recount must stop; Al Gore conceded the election within twentyfour hours. ${ }^{237}$ This efficacious a ruling, on this divisive an issue, is certain to generate tremendous resentment toward the Court.

As to the relative power of the constituencies impacted by the Court's decision, both Democrats and Republicans have plenty of political and economic clout in American society. Thus, Bush v. Gore is not a case where the Court's critics are relatively disadvantaged in the public relations battle that follows the ruling. On the other hand, it is hard to think of a constitutional issue that is more destined to become obsolete. George W. Bush will be president, possibly as a result of the Supreme Court's rulmg, for four years. If he serves eight years, an intervening independent cause, a second electoral victory, will greatly reduce the Court's responsibility for the second term. There is unlikely to be another presidential election like

Top Democrats Rally Behind Gore, WASH. Post, Nov. 28, 2000, at Al0 (noting that "several Democratic lawmakcrs said they are so angry at what they consider inflammatory GOP rhetoric that they are increasingly committed to Gore's cause"); see also Thomas E. Mann, Gore Owes It to Nation to Fight On, Boston GloBe, Nov. 28, 2000, at A 15, reprinted in BusH v. Gore, supra note 20, at 204, 205 ("In 30 years of watching Congress and the presidency, I have never encountered rhetoric as vituperative and destructive of the constitutional order as has emanated from established figures in the Republican Party and their partisan allies.").

236. See supra note 45; David Von Drehle et al., Anxious Moments in the Final Stretch, WAsH. PosT, Feb. 3, 200I, at AI ("The initial Bush appeal had been a suit that all the law professors said the [Supreme Court] would never take....”); Maggie Mulvihill, Case Unlikely to Go to High Court, Boston HeralD, Nov. 18, 2000, at 4 (noting that "[1] egal experts doubt that the matter will be taken up by the highest court in the land"); Larry Lipman \& Kathy Pruitt, Did Fla. Court Go Too Far?, Atlanta J. AND Const., Nov. 25, 2000, at A7 (noting that "[t]he Supreme Court's decision to hear Bush's appeal came as a surprise"); Joan Biskupic, Courts Can't Unravel All Election Snags, USA TODAY, Nov. 17, 2000, at IA (predicting that "the black-robed nine in Washington will beg off"); David G. Savage \& Henry Weinstein, America Waits, L.A. TIMES, Nov. 23, 2000, at A24 ("Most legal experts agreed that there [were] long odds against Bush's actually winning in the Supreme Court ...."). But see Einer Elhauge, Bush v. Florida, N.Y. Times, Nov. 20, 2000, at A27 (stating that if the Florida Supreme Court orders a manual recount, "no one should be surprised if the U.S. Supreme Court steps in").

237. One can only marvel at the enormous prestige of an institution that could command such total obedience to such a lawless decision. Imagine how different the reaction of the Jeffersonians would have been two hundred years earlier had counterfactual litigation resulted in a Federalist Supreme Court awarding victory to John Adams (or Aaron Burr) in the disputed presidential election of 1800 . The Marshall Court was too intimidated by the Jefferson administration even to order the Secretary of State to deliver commissions to justices of the peace appointed by outgoing President Adams. See Marbury v. Madison, 5 U.S. (I Cranch) 137 (I803). The idea of that Court attempting to adjudicate the results of a presidential election (and having anyone pay attention to its determination, should it dare to do so) is simply incomprehensible. 
this past one during the lifetime of anyone now living. Moreover, the Supreme Court's ruling in Bush, by design, will have implications for no other constitutional issue; the Justices in the majority made clear their intention to treat the decision as "good for this day and train only."2338 Memories of what most Democrats will regard as the (at least attempted) judicial theft of a presidential election will survive, but they will be just that-memories. Bush's presence in the White House for four years will constitute a short-term reminder of the Court's decision. But this is not like the abortion issue, which just will not go away, and thus serves as a constant reminder to right-to-lifers of Supreme Court decisions like Roe and Casey.

On the other hand, unlike with racial segregation, where public opinion transformed over time, popular attitudes toward Bush $v$. Gore probably never will change very much. Democrats are likely always to believe that the Supreme Court intervened in the 2000 presidential election because the conservative Justices preferred George W. Bush for president. ${ }^{239}$ Perhaps some attitudes will change if Bush proves to be a particularly good or bad President, ${ }^{240}$ but probably not too many. Moreover, unlike with the death penalty, the Supreme Court almost certainly will enjoy no future opportunities to revisit the issue in Bush, as it did in Furman, and thus to fix its "mistake." Once elected president, Bush cannot be "unelected."

Finally, from the "basket of issues" perspective, the Rehnquist Court might survive Bush v. Gore reasonably unscathed, because the remainder of the Court's constitutional jurisprudence has been such a political grab bag of results. Bush might have enraged Democrats even more had the conservative majority that ensured Bush's election been consistently writing conservative values into the Constitution. But it has not. While the Rehnquist Court arguably has been the most activist in history, ${ }^{241}$ its activism does not manifest a consistent political valence. In recent years, liberals generally have won on issues involving abortion, school prayer, gender discrimination, and freedom of speech. ${ }^{242}$ Conservatives, on the other hand,

238. Smith v. Allwright, 321 U.S. 649,669 (1944) (Roberts, J., dissenting). See supra text accompanying notes 37-39.

239. See, e.g., Michael W. McConnell, A Muddled Ruling, Wall St. J., Dec. 14, 2000, at A26 ("Many of the vice-president's supporters will continue to believe-probably to their graves-that their man would have won if only they had been given more time.").

240. See, e.g., Kaiser, supra note 15, at A25 (reporting former White House counsel A.B. Culvahouse's view that if Bush is a successful president, "lots of people" may end up approving of the Court's ruling).

241. Cf. Larry D. Kramer, No Surprise. It's an Activist Court, N.Y. Times (late ed.), Dec. 12, 2000, at A33, reprinted in BusH v. GorE, supra note 20, at 273-75 (noting that, given the extraordinary activism of the Rehnquist Courh, its decision in Bush should have come as no surprise).

242. See, e.g., Planned Parenthood of Southeastern Pennsylvania v. Casey, 505 U.S. 833 (1992) (abortion); Lee v. Weisman, 505 U.S. 577 (1992) (school prayer); United States v. Virginia, 518 U.S. 515 (1996) (exclusion of women from Virginia Military Institute); Texas v. Johnson, 491 U.S. 397 (1989) (flag burning). 
have triumphed on issues such as affirmative action, minority voting districts, public aid to parochial schools, federalism, the death penalty, and (usually) criminal procedure. ${ }^{243}$ Indeed, in the term that immediately preceded Bush, the Court issued a series of important constitutional rulings that were noteworthy mainly for the political evenhandedness of the results. ${ }^{244}$ Liberals won on abortion rights, access to abortion clinics, school prayer, and the continued vitality of Miranda. ${ }^{245}$ Conservatives won on several important federalism issues, public aid to parochial schools, and the First Amendment rights of organizations that discriminate against gays. ${ }^{246}$ Perhaps Democratic ire over Bush v. Gore is somewhat ameliorated by the Rehnquist Court's continuing propensity to distribute a substantial share of constitutional victories to liberals. Imagine how differently conservatives might have reacted to a counterfactual Warren Court ruling in 1968 handing the presidential election to Hubert Humphrey.

\section{Conclusion}

Where does consideration of these various factors leave us in evaluating the likely impact of Bush v. Gore on the Court's long-term legitimacy? Roughly half the nation probably will believe for the indefinite future that the Supreme Court stole (or at least attempted to steal) a presidential election from their candidate. Yet, after a brief four years has passed, Bush v. Gore will become an unhappy inemory rather than a constant irritant. Thus, Bush seems unlikely to harm the Court's standing very much, especially if the Justices' constitutional jurisprudence continues to manifest the uneven political valence that it has in recent years.

The one confident prediction that can be made is that the Senate confirmation hearings of future Supreme Court nominees are likely to

243. See, e.g., City of Richmond v. J.A. Croson Co., 488 U.S. 469 (1989) (affirmative action); Shaw v. Reno, 509 U.S. 630 (1993) (minority voting districts); Agostini v. Felton, 521 U.S. 203 (1997) (public aid to parochial schools); United States v. Lopez, 514 U.S. 549 (federalism); McClesky v. Kemp, 481 U.S. 279 (1987) (death penalty); Michigan Dep't of State Police v. Sitz, 496 U.S. 444 (1990) (sobriety checkpoints permissible under the Fourth Amendment).

244. See, e.g., Edward Walsh, An Activist Court Mixes Its High-Profile Message, Wash. Post, July 2, 2000, at A6; Kathleen M. Sullivan, A Court Not Easy to Classify, N.Y. Trmes, June 29, 2000, at $\mathrm{A} 31$ ("[ $] \mathrm{n}$ the rich and important term that just finished yesterday, the justices defied any simple political typecasting ....").

245. Stenberg v. Carhart, 530 U.S. 914 (2000) (abortion); Hill v. Colorado, 530 U.S. 703 (2000) (abortion clinics); United States v. Dickerson, 530 U.S. 428 (affirming Miranda); Santa Fe Independent School Dist. v. Doe, 530 U.S. 290 (2000) (school prayer).

246. Mitchell v. Helms, 530 U.S. 793 (2000) (public aid to parochial schools); Boy Scouts of America v. Dale, 530 U.S. 640 (2000) (First Amendment right to exclude gays); United States v. Morrison, 529 U.S. 598 (2000) (invalidating Violence Against Women Act on federalism grounds); Kimel v. Florida Bd. of Regents, 528 U.S. 62 (2000) (invalidating congressional imposition of damages liability upon states under the Age Discrimination in Employment Act). 
resemble a war zone. ${ }^{247}$ This already has been true inuch of the time since the late 1960s; consider the fierce battles over the nominations of Justice Abe Fortas (for promotion to Chief Justice), Judges Clement Haynesworth and Harold Carswell, Judge Robert Bork, and Justice Clarence Thomas. ${ }^{248}$ And why should we not expect it to be so, as the Supreme Court increasingly has asserted jurisdiction over the issues that comprise today's culture wars? Now that the Justices not only make national policy on abortion, school prayer, and affirmative action, but also pick presidents, the stakes of a Supreine Court appointment, especially on this narrowly-divided Court, will be ratcheted that much higher. This battlefield scenario is especially likely to unfold when President George W. Bush makes his first nomination to the Court. Since most Democrats believe that the Court's intervention to make Bush president was illegitimate, they are sure to scrutinize with exacting care his efforts to reshape the Court in his political image. While Democrats proved powerless to prevent the Court from picking the president, they may have greater success, especially in this closely-divided Senate, at preventing the president from picking the Court.

247. See, e.g., Kaiser, supra note 15, at A25 (reporting legal historian Howard Gillman's view that Bush is likely to affect the appointments process for Supreme Court Justices); Stephen Fidler, U.S. Election: The Final Chapter, FIN. Tmes (London), Dec. 14, 2000, at 12 (reporting similar views of Professors A.E. Dick Howard and Stephen Wermeil); Scot Lehigh, So, Class, What Have We Learned? Were the Bush-Gore Lessons Lasting or Was It Just Another Battle?, Boston GLOBE, Dec. 17, 2000, at C1 (quoting political scientist Nelson Polsby predicting a "terrible confirmation battle" over Bush's first Supreme Court nomination).

248. See generally Ethan BronNer, Battle for Justice: How the Bork Nomination Shook America (1989); John Paul Frank, Clement Haynsworth, the Senate, and the Supreme Court (1991); Laura Kalman, Abe Fortas: A Biography (1990); Jane Mayer \& Jill Abramson, Strange Justice: The Selling of Clarence Thomas (1994). 
[Vol. 89:1721 